\title{
Bibliometry of Articles and Theses Published in the National Field on Ethics in Hotel Organizations
}

\author{
Otel Işletmelerinde Etik Konulu Ulusal Alanyazında \\ Yayınlanmış Olan Makale ve Tezlerin Bibliyometrisi
}

\begin{abstract}
In this study, made in Turkey between the years of 2000-2020 "ethics in hotel organizations" it is intended to be examined under a variety of articles and theses on bibliometric parameters. This review is considered to be important in terms of providing information to businesses in the hotel industry and academicians who want to study ethics. In the literature review conducted for this purpose, 22 theses published in the Higher Education National Thesis Center and open to access, and 28 articles were found as a result of the search made through Google Scholar. The accessed articles and theses were examined in terms of bibliometric features such as the number of authors, the academic title of the authors, the type of the study, the year the study was conducted, and the universities to which the authors were affiliated. As a result of the research, it was seen that empirical studies were intense and conceptual studies were few in the majority of articles and theses. In addition, it was determined that the authors who made the most studies on the subject had the title of Assistant Professor. Conceptual evaluations were made at the end of the study and suggestions were made for similar studies to be conducted in the future.

Keywords: Hotel organizations, ethic, tourism, bibliometric analysis

\section{Öz}

Bu çalışmada, 2000-2020 yılları arasında Türkiye'de yapılmış olan "otel işletmelerinde etik" konulu makale ve tezlerin çeşitli bibliyometrik parametreler kapsamında incelenmesi amaçlanmıştır. Yapılan bu incelemenin, otelcilik sektöründe yer alan işletmelere ve etik konusunda çalışma yapmak isteyen akademisyenlere bilgi sağlaması açısından önem arz ettiği düşünülmektedir. Bu amaçla yapılan yazın taramasında Yükseköğretim Ulusal Tez Merkezi'nde yayınlanmış ve erişime açık olan 22 teze ve Google Akademik üzerinden yapılan tarama sonucu 28 adet makaleye ulaşıımıştır. Ulaşılan makale ve tezler, yazar sayısı, yazarların akademik unvanı, çaıışmanın türü, çalışmanın yapıldığı yıl ve yazarların bağlı oldukları üniversiteler gibi bibliyometrik özellikleri açısından incelenmiştir. Araştırma sonucunda, makale ve tezlerin büyük çoğunluğunda ampirik çalışmaların yoğun olduğu, kavramsal çalışmaların az sayıda olduğu görülmüştür. Ayrıca, konu ile ilgili en çok çalışma yapan yazarların ise Doktora Öğretim Üyesi unvanına sahip olduğu tespit edilmiştir. ÇaIışmanın sonunda kavramsal değerlendirmeler yapılarak, gelecekte yapılacak olan benzer çalışmalar için önerilerde bulunulmuştur.
\end{abstract}

Anahtar Kelimeler: Otel işletmeleri, etik, turizm, bibliyometrik analiz

\section{Derya TURAN SUNAR (iD}

İstanbul Üniversitesi, Sosyal Bilimler Enstitüsü, Turizm Işletmeciliği Anabilim Dalı, İstanbul, Türkiye
Cite this article as: Turan Sunar, D. (2021). Bibliometry of Articles and Theses Published in the National Field on Ethics in Hotel Organizations. Journal of Business Administration and Socia Studies, 5(1), 1-14

Corresponding Author: Derya TURAN SUNAR E-mail: drytrn87@gmail.com

Received: 14 Ağustos 2020

Accepted: 13 Aralık 2020

\section{(c) $(1) \Theta$}

Copyright@Author(s) - Available online at www.j-ba-socstud.org

Content of this journal is licensed under a

Creative Commons Attribution-NonCommercial 4.0 International License.

\section{Giriş}

Küresel rekabet içinde yer alan işletmeler için önemli bir rekabet aracı haline gelen etik, aynı şekilde gerek ulusal gerekse uluslararası düzeyde faaliyet gösteren otel işletmeleri için de önemli bir konu olarak görülmektedir. Otelcilik sektöründe insan unsurunun ön planda olması, etik dışı davranışların daha fazla tartışılmasına ve araştırılmasına neden olmaktadır. İşletmelerde en çok görülen etik dışı davranışlar ise; ayrımcılık, adam kayırma, yıldırma, psikolojik baskı, görevi kötüye kullanma, hakaret, küfür, yetkiyi kötüye kullanma, bencillik, taciz, dedikodu yapma gibi davranışlardır (Akova ve ark., 2015).

Turizm hareketlerinin ve yatırımlarının; küreselleşmenin hız kazanmasıyla yaşanan gelişmeler doğrultusunda uluslararası boyuta ulaşması, sektörde birinci derecede hizmet veren otel işletmeleri, seyahat işletmeleri, ulaştırma işletmeleri, eğlence ve rekreasyon işletmelerinin taleplerinde de yoğunluk yaşanmasına aracı olmuştur. Artan yoğunluk işletmeler arasındaki rekabet ortamını arttırmış, işletmelerin başarılı ve sür- 
Tablo 1

Otel Işletmeleri ve Turizm ile IIgili Bibliyometrik Çalışmalar

Evren, \& Kozak, (2012)

Arslan, \& Emeksiz, (2016)

Boğan ve ark., (2018)

Baytok ve ark., (2019)
Türkiye'de 2000-2010 yılları arasında yayınlanan turizm konulu makalelerin bibliyometrik analizi

Konaklama işletmelerinde çevre yönetimi konusunun bibliyometrik profili ve gelecek çalışmalar için öneriler

Turizm yazınında kurumsal sosyal sorumluluk: Türkiye'de yapılan çalışmaların bibliyometrik analizi

Etik ve sosyal sorumluluk konulu bildirilerin bibliyometrisi: Ulusal Turizm Kongreleri Örneği (2009-2017) dürülebilir olabilmeleri benimsemiş oldukları etik yönetim anlayışlarına bağlı hale gelmiştir. Otel işletmelerinde insan emeğinin yoğun olması sebebiyle etik olmayan uygulamalara diğer işletmelere göre daha sık rastlanmak mümkündür (ipar, \& Esmer, 2015). Bu nedenle, etik birçok araştırmacının ilgisini çeken bir konu olmuştur.

Ulusal alanyazın incelendiğinde otel işletmeleri ve turizm ile ilgili pek çok bibliyometrik çalışma yapıldığı görülmektedir. Bu çalışmalar Tablo l'de detaylı bir şekilde gösterilmiştir. Görüldüğü üzere yazarlar; turizm, konaklama işletmelerinde çevre yönetimi, turizm yazınında kurumsal sosyal sorumluluk, etik ve sosyal sorumluluk gibi konular üzerine bibliyometrik analizler yapmışlardır. Ancak "otel işletmelerinde etik" konusu ile ilgili yayınlanan makale ve tezlerin incelenmesine yönelik herhangi bir çalışma bulunmadığı tespit edilmiştir. Bu doğrultuda, çalışmada ulusal alanyazında yayınlanmış olan otel işletmelerinde etik konulu makale ve tezlerin çeșitli bibliyometrik parametreler açısından incelenmesinin alanyazındaki boşluğu dolduracağı düşünülmektedir. Bu amaçla, 20002020 yılları arasındaki 20 yıllık dönem incelenmiştir. Otel işletmelerinde etik konulu 28 makale ve 22 adet teze ulaşılmış ve bu çalışmalar yazar sayısı, yazarların akademik unvanı, çalışmanın türü, çalışmanın yapıldığı yıl ve yazarların bağlı oldukları üniversitelere göre incelenmiştir.

Bu çalışmada sadece ulusal alanyazının incelenmiş olması bu araştırmanın sınırlılığıdır. Araştırma kapsamına dahil edilen tezlere YÖK Ulusal Tez Merkezi sitesinden ulaşılmış olup sadece kayıtlı ve erişime açık tezler değerlendirmeye alınmıştır. Bu durum, henüz ilgili internet sitesine girişi yapılmamış tezlerin kapsam dışı kalmasına neden olmuş olabilir. Araştırma kapsamına dahil edilen makalelere ulaşmak için ise yalnızca Google Akademik sitesinde tarama yapılmıştır. Bu internet sitesinin seçilmesinin nedeni ise, yerel akademisyenlerin ve çalışmaların yer aldığı kapsamlı bir portal olmasıdır.

\section{Otel İşletmelerinde Etik}

Etik, milattan önce Aristoteles tarafından ortaya konulmuş kökeni "ethos" sözcüğüne dayanan bir felsefe dalıdır (Tütüncü, \& Savran, 2007). Kavram olarak, töre, görenek, adet gibi anlamlara gelse de genel olarak toplumdaki birey ya da kurumların davranışlarının doğru ya da yanlış, iyi ya da kötü olma durumlarını sorgulayan değerlerdir (ipar, \& Esmer, 2015; Mirze 2010). Türk Dil Kurumu tarafından yapılan tanıma göre ise etik; "çeşitli meslek kolları arasında tarafların uyması veya kaçınması gereken davranışlar bütünü” dür (Türk Dil Kurumu, 2020).

Disiplinler arası bir endüstri olması nedeniyle turizm farklı toplumsal yapılar ve doğal çevre ile yakın ilişki içerisindedir. Turizm endüstrisi içerisinde kendi çıkarlarını gözeten birçok paydaşın bulunması, etik sorunların da ortaya çıkmasına neden olmaktadır. Bu nedenle turizmde etik olgusunun tartışılmasına ve incelenmesine gerek duyulmaktadır (Fennell, \& Prezeclswki, 2003). Turizm işletmecileri ve yatırımcılar açısından bakıldığında maliyetleri en aza indirmek ve yüksek oranda kar elde etmek ön plandayken, turistler için kısıtlı boş zamanında bütçesine uygun, düşük maliyetli tatil seçenekleri öne çıkmaktadır. Sektörde çalışanlar için işletmenin çalışma olanaklarının (maaş, terfi, kariyer vb.) standartları önemliyken, bölgede yaşayan yerel halk için ise sektörün sağlayacağı toplumsal faydalar (alt yapı imkânları, eğitim seviyesinin artması, kadınların aktif olarak iş hayatında yer alması vb.) önemli olmaktadır (ipar, \& Esmer, 2015. Görüldüğü üzere işletmenin içinde bulunduğu bölgedeki paydaşlar için farklı çıkarlar ve istekler söz konusudur. Bu durum, turizm sektöründeki faaliyetlerin etik yönünün incelenmesini zorunlu kılmaktadır. Bu anlamda atılan ilk adım Türkiye'nin de katılım göstermiş olduğu ve 1997 yılında İstanbul'da gerçekleşen Dünya Turizm Örgütü genel kurulunda, Küresel Etik IIlkelerinin (Global Code of Ethics) hazırlandığı komite olmuştur (Arslan ve Kozak, 2006). Birleşmiş Milletler Dünya Turizm Örgütü 1 Ekim 1999 tarihinde Santiago-Şili'de gerçekleştirdiği 13. Genel Kurulu'nda tüzüğünün 3. maddesinde yer alan amaçlar doğrultusunda; "ekonomik gelişmeye, uluslararası anlayışa, barış, refah, insanın temel hak ve özgürlüklerine, ırk, cinsiyet, dil ve din ayrımı yapılmaksızın herkese evrensel saygı duyularak turizmin teşvik ve geliştirilmesinin sağlanmasında, dünya turizminin sorumlu ve sürdürebilir gelişiminin sağlanmasında esas oluşturacak 10 maddelik ilkeleri "Turizm için Küresel Etik Kurallar" adı altında kabul ve beyan etmiştir". Kabul edilen bu on madde şu şekildedir (TÜRSAB, 2020):

1. Turizmin insanlar ve toplumlar arasındaki karşılıklı anlayış ve saygıya katkısı,

2. Bireysel ve kolektif gelişim aracı olarak turizmin önemi,

3. Sürdürülebilir gelişmenin bir öğesi olarak turizmin önemi,

4. Turizmin insanlığın kültürel mirasını kullanan ve zenginleştiren unsurları,

5. Turizmin turist kabul eden ülkeler ve topluluklar için yararlı bir etkinlik olması,

6. Turizmin geliştirilmesinde tarafların yükümlülükleri,

7. Turizme katılma hakkı,

8. Turizm hareketlerinde özgürlük,

9. Turizm sektöründe çalışanların ve girişimcilerin hakları,

10. Turizm için küresel etik kuralların uygulanması.

Otel işletmelerinin emek yoğun özelliği nedeniyle hizmetin hem üretim hem de pazarlama aşamasında neredeyse tüm çalışanlar aktif olarak yer almaktadır. Özellikle, turistler ile yüz yüze iletişimi daha fazla olan çalışanların davranış ve tutumları etik değerler çerçevesi içinde olmalıdır (Varinli, 2004). Otel işletmelerinde etik problemlerin en çok yaşandığı departmanlardan biri insan kaynakları departmanıdır. Iş̧letme içinde çalışan elamanların eşit çalışma koşullarına sahip olmaması, mesai saatlerinin ve molaların düzensizliği ve çalışan haklarının verilmemesi, terfi ve ödül sistemlerinde eşitsizlik ve personel alımlarında yapılan adaletsizlik en çok rastlanan etik dışı davranışlardandır (Pelit, \& Arslantürk, 2011). Bu gibi durumlar çalışanların işletmeye olan güvenini ve sadakatini zedeleyen durumlardır. Ayrıca işletmede çalışan bireyler hangi durumların etik, hangilerinin etik dışı olduğunu anlamakta zorluk çekebilirler. Bu nedenle, işletme sahipleri ve yöneticilerinin öncelikle çalışanlarına karşı etik davranmaları ve etik davranışa yönlendirecek kural ve uygulamaları bulunmalıdır.

\section{Araştırma Yöntemi}

Bibliyometrik analiz, herhangi bir alanyazınında yayınlanmış olan kitap, dergi, makale gibi bilimsel çalışmaların nicel analiz ile çeşitli parametreler açısından (konuların ele alınış şekilleri, yazar sayısı, yazar unvan- 


\begin{tabular}{|c|c|c|c|c|c|}
\hline Yazar & Yayın Yeri & Çalışmanın Başı̆̆ı & $\begin{array}{l}\text { Veri Toplama } \\
\text { Aracı }\end{array}$ & Amacı & Sonucu \\
\hline $\begin{array}{l}\text { Varinli, } \\
(2004)\end{array}$ & $\begin{array}{l}\text { Ege Akademik } \\
\text { Bakış Dergisi }\end{array}$ & $\begin{array}{l}\text { Hizmet İşletmelerinde } \\
\text { Çalışanların Etik Olmayan } \\
\text { Davranışlara İlişkin } \\
\text { Değerlendirmeleri } \\
\text { Otel İşletmelerinde Bir } \\
\text { Uygulama }\end{array}$ & Anket & $\begin{array}{l}\text { Otel işletmelerinde çeşitli } \\
\text { düzeylerde çalışanların etik } \\
\text { olmayan uygulamalara dair } \\
\text { düşüncelerini öğrenmek. }\end{array}$ & $\begin{array}{l}\text { Genel olarak çalışanların etik olmayan } \\
\text { uygulamaları onaylamadıkları, } \\
\text { çalışanların işletmedeki pozisyonlarına } \\
\text { göre değerlendirmelerinin farklı olduğu } \\
\text { bulunmuştur. Ayrıca, işletme ölçeğine } \\
\text { göre çalışanların bazı etik olmayan } \\
\text { uygulamalarda biraz daha esnek } \\
\text { oldukları görülmüştür. }\end{array}$ \\
\hline $\begin{array}{l}\text { Sarışı।k ve ark., } \\
(2006)\end{array}$ & $\begin{array}{l}\text { Anatolia: } \\
\text { Turizm } \\
\text { Araştırmaları } \\
\text { Dergisi }\end{array}$ & $\begin{array}{l}\text { Otel Yöneticilerinin Etik } \\
\text { Politika ve Yöntemlere } \\
\text { Yaklaşımları Üzerine } \\
\text { Ampirik Bir Araştırma }\end{array}$ & Anket & $\begin{array}{l}\text { Otel yöneticilerinin otellerdeki } \\
\text { etik politika ve yöntemler ile etik } \\
\text { uygulamalar konusundaki görüş } \\
\text { ve algılarını ortaya çıkarmak. }\end{array}$ & $\begin{array}{l}4 \text { ve } 5 \text { yıldızlı otel işletmelerinin } \\
\text { yöneticileri tarafından doldurulan } \\
\text { anketlerin değerlendirilmesi } \\
\text { sonucunda işletmelerin farklı sınıflarda } \\
\text { olmasına karşılık, yöneticilerinin etik } \\
\text { değer yargılarına bakış açıları arasında } \\
\text { önemli farklılıklar olmadığı tespit } \\
\text { edilmiştir. }\end{array}$ \\
\hline $\begin{array}{l}\text { Bektaş, } \\
\text { (2008) }\end{array}$ & $\begin{array}{l}\text { Ticaret ve } \\
\text { Turizm Eğitim } \\
\text { Fakültesi } \\
\text { Dergisi }\end{array}$ & $\begin{array}{l}\text { Etik Kodların Otel } \\
\text { Endüstrisine Katkıları ve } \\
\text { Bir Alan Araştırması }\end{array}$ & Anket & $\begin{array}{l}\text { Etik kodların otel endüstrisine } \\
\text { katkılarını araştırmak }\end{array}$ & $\begin{array}{l}\text { Etik kodların otel endüstrisinde } \\
\text { büyük oranda katkısının olacağı } \\
\text { tespit edilmiştir. Ancak işletmelerin } \\
\text { etik konusunda yaptığı çalışmaların } \\
\text { yetersiz olduğu gözlemlenmiştir. }\end{array}$ \\
\hline $\begin{array}{l}\text { Akşit Aşık, } \\
\text { (2009) }\end{array}$ & $\begin{array}{l}\text { Akademik } \\
\text { Fener }\end{array}$ & $\begin{array}{l}\text { Konaklama } \\
\text { İşletmelerinde } \\
\text { Çalışanların } \\
\text { Yöneticilerin Tutum ve } \\
\text { Davranışlarını Etik Açıdan } \\
\text { Değerlendirmelerine } \\
\text { Yönelik Bir Araştırma }\end{array}$ & Anket & $\begin{array}{l}\text { Konaklama işletmelerinde } \\
\text { çalışanların, yöneticilerin etik } \\
\text { olmayan uygulamalarına ilişkin } \\
\text { değerlendirmeleri ve etiği } \\
\text { algılama biçimlerinin belirlenmesi. }\end{array}$ & $\begin{array}{l}\text { İşletme büyüklüğü ile yöneticilerin etik } \\
\text { olmayan davranışları arasında anlamlı } \\
\text { farklılıklar belirlenmiş, çalışanların etik } \\
\text { davranışları değerlendirme biçimlerinin } \\
\text { bireysel farklııklar gösterdiği } \\
\text { sonucuna varılmıştır. }\end{array}$ \\
\hline $\begin{array}{l}\text { Öğüt, \& Kaplan, } \\
\text { (2011) }\end{array}$ & $\begin{array}{l}\text { Dumlupınar } \\
\text { Üniversitesi } \\
\text { Sosyal Bilimler } \\
\text { Dergisi }\end{array}$ & $\begin{array}{l}\text { Otel İşletmelerinde } \\
\text { Etiksel İklim Algılamaları } \\
\text { ile Örgütsel Bağlılık } \\
\text { Arasındaki Illş̧kinin } \\
\text { Analizi: Kapadokya } \\
\text { Örneği }\end{array}$ & Anket & $\begin{array}{l}\text { Kapadokya bölgesindeki } 4 \text { ve } \\
5 \text { yıldızlı otel işletmelerinde } \\
\text { çalışan işgörenlerin etiksel iklim } \\
\text { algılamaları ile örgütsel bağlııkları } \\
\text { arasındaki ilişskileri analiz etmek, } \\
\text { ayrıca etiksel iklim algılamalarının } \\
\text { örgütsel bağlılık üzerindeki } \\
\text { etkisini ortaya koymak. }\end{array}$ & $\begin{array}{l}\text { Başkalarının iyiliğini isteme, kanun ve } \\
\text { kod ve kurallar iklim tipleri ile duygusal } \\
\text { ve normatif bağlııık arasında pozitif } \\
\text { yönlü, araçsallık iklim tipi ile duygusal } \\
\text { bağlııı arasında negatif yönlü ilişki } \\
\text { olduğu belirlenmiştir. Ayrıca, etiksel } \\
\text { iklim algılamalarının normatif ve } \\
\text { devam bağlı̆ı̆ı üzerinde etkili olmadığı } \\
\text { bulgusuna ulaşıımıştır. }\end{array}$ \\
\hline $\begin{array}{l}\text { Tuna ve ark., } \\
\text { (2012) }\end{array}$ & $\begin{array}{l}\text { Atatürk } \\
\text { Üniversitesi } \\
\text { İktisadi ve İdari } \\
\text { Bilimler Dergisi }\end{array}$ & $\begin{array}{l}\text { Etik Liderlik Ölçeğinin } \\
\text { Geçerlilik ve Güvenilirlik } \\
\text { Çalışması: Antalya Örneği }\end{array}$ & Anket & $\begin{array}{l}\text { Etik liderlik uygulamalarının } \\
\text { ölçülmesi ve etik liderlik olgusuna } \\
\text { yapısal ve denemesel bir } \\
\text { tanımlama getirilmesi temel hedef } \\
\text { olarak belirlenmiştir. Bu maksatla, } \\
\text { EL ölçeğinin Türkçe geçerlilik ve } \\
\text { güvenilirliğini yapmak. }\end{array}$ & $\begin{array}{l}\text { Ölçeğin Türkiye'de de etik liderlik } \\
\text { uygulamalarını ölçebilecek nitelikte } \\
\text { olduğu ve yeterli geçerlilik ve } \\
\text { güvenilirliğe sahip olduğu tespit } \\
\text { edilmiştir }\end{array}$ \\
\hline $\begin{array}{l}\text { Ünlüönen, \& } \\
\text { Arslan, (2012) }\end{array}$ & $\begin{array}{l}\text { Elektronik } \\
\text { Sosyal Bilimler } \\
\text { Dergisi }\end{array}$ & $\begin{array}{l}\text { Otel İşletmelerinde } \\
\text { Çalışanların Paraya Olan } \\
\text { Tutumunun Mesleki } \\
\text { Etik Değerler Açısından } \\
\text { İncelenmesi }\end{array}$ & Anket & $\begin{array}{l}\text { Mesleki etik kavramını turizm } \\
\text { işletmelerinde inceleyerek } \\
\text { mesleki etiğin para olgusu } \\
\text { üzerinde etkisinin olup olmadığını } \\
\text { incelemek. }\end{array}$ & $\begin{array}{l}\text { Otel işletmelerinde çalışanların paraya } \\
\text { olan tutumları azaldıkça mesleki etik } \\
\text { değerlere verdikleri önemin artacağı } \\
\text { tespit edilmiştir. }\end{array}$ \\
\hline
\end{tabular}




\begin{tabular}{|c|c|c|c|c|c|}
\hline Yazar & Yayın Yeri & Çalışmanın Başlığı & $\begin{array}{l}\text { Veri Toplama } \\
\text { Aracı }\end{array}$ & Amacl & Sonucu \\
\hline $\begin{array}{l}\text { Yeşiltaş ve ark., } \\
\text { (2012) }\end{array}$ & $\begin{array}{l}\text { Muğla } \\
\text { Üniversitesi } \\
\text { Sosyal Bilimler } \\
\text { Enstitüsü } \\
\text { Dergisi }\end{array}$ & $\begin{array}{l}\text { Etik Liderlik ve Örgütsel } \\
\text { Adaletin Örgütsel Sapma } \\
\text { Davranışları Üzerindeki } \\
\text { Etkisi }\end{array}$ & Anket & $\begin{array}{l}\text { Etik liderlik ve örgütsel adaletin } \\
\text { örgütsel sapma davranışları } \\
\text { üzerinde etkili olup olmadığını } \\
\text { araştırmak. }\end{array}$ & $\begin{array}{l}\text { Araştırmada ortaya çıkan etik } \\
\text { liderlik davranışları ile sapma } \\
\text { davranışlar arasındaki negatif yönlü } \\
\text { ilişki etik liderlik faaliyetlerinin } \\
\text { sapma davranışlarını azaltacağını } \\
\text { göstermektedir. }\end{array}$ \\
\hline $\begin{array}{l}\text { Tuna, \& } \\
\text { Yeşiltaş, } \\
\text { (2013) }\end{array}$ & $\begin{array}{l}\text { İşletme } \\
\text { Araştırmaları } \\
\text { Dergisi }\end{array}$ & $\begin{array}{l}\text { Liderliğin Etik Boyutu: } \\
\text { Etik Liderliğin Otel } \\
\text { İşletmelerindeki } \\
\text { İşgörenler Tarafından } \\
\text { Algılanması }\end{array}$ & Anket & $\begin{array}{l}\text { Otel işletmelerindeki iş } \\
\text { görenlerin bireysel ve işletme } \\
\text { özellikleri çerçevesinde etik } \\
\text { liderlik algılamalarının değişip } \\
\text { değişmediği araştırmak. }\end{array}$ & $\begin{array}{l}\text { İşletmenin sahiplik yapısı, yaş } \\
\text { değişkeni ve iş yerinde hizmet süresi } \\
\text { ile etik liderlik arasında anlamlı bir } \\
\text { farklıık tespit edilmiştir. }\end{array}$ \\
\hline $\begin{array}{l}\text { Sökmen, \& } \\
\text { Ekmekçioğlu, } \\
\text { (2013) }\end{array}$ & $\begin{array}{l}\text { İşletme } \\
\text { Araştırmaları } \\
\text { Dergisi }\end{array}$ & $\begin{array}{l}\text { Yönetici Etik } \\
\text { Davranışlarının Sınır Birim } \\
\text { Çalışanlarının Motivasyon } \\
\text { ve İ̧̧ Tatmini Üzerindeki } \\
\text { Etkisi: Adana'da Bir } \\
\text { Araştırma }\end{array}$ & Anket & $\begin{array}{l}\text { Yönetici etik davranışlarının } \\
\text { çalışanlar tarafından nasıl } \\
\text { algılandığından yola çıkılarak, } \\
\text { Adana ilinde faaliyet } \\
\text { gösteren dört ve beş yıldızlı } \\
\text { konaklama işletmelerinde bu } \\
\text { etik davranışların sınır birim } \\
\text { çalışanlarının motivasyon ve iş } \\
\text { tatminleri üzerindeki etkisini } \\
\text { belirlemek. }\end{array}$ & $\begin{array}{l}\text { Yöneticilerin etik davranışlarına yönelik } \\
\text { olumlu algının sınır birim çalışanlarının } \\
\text { motivasyonlarını ve iş tatminlerini } \\
\text { olumlu olarak etkilediği, ayrıca çalışan } \\
\text { motivasyonunun da iş tatmini üzerinde } \\
\text { olumlu etkisi olduğu saptanmıştır. }\end{array}$ \\
\hline $\begin{array}{l}\text { Pelit, \& } \\
\text { Bozdoğan, } \\
\text { (2014) }\end{array}$ & $\begin{array}{l}\text { İşletme } \\
\text { Araştırmaları } \\
\text { Dergisi }\end{array}$ & $\begin{array}{l}\text { Çalışanların Örgütsel } \\
\text { Adalet Algılamalarının } \\
\text { Tükenmişlik Düzeyleri } \\
\text { Üzerindeki Etkisi: } \\
\text { Kemer'deki Beş Yıldızlı } \\
\text { Otel İşletmelerinde Bir } \\
\text { Uygulama }\end{array}$ & Anket & $\begin{array}{l}\text { Otel işletmelerinde çalışan } \\
\text { işgörenlerin örgütsel adalet } \\
\text { algılamalarının tükenmişlik } \\
\text { düzeyleri üzerindeki etkisinin } \\
\text { belirlenmesi. }\end{array}$ & $\begin{array}{l}\text { Örgütsel adalet ile tükenmişlik } \\
\text { arasında negatif yönlü orta düzeyde } \\
\text { bir iliş̧ki olduğu tespit edilmiştir. } \\
\text { Bu değer işletmelerdeki örgütsel } \\
\text { adalet algısının artmasıyla birlikte } \\
\text { çalışanların tükenmişlik düzeyinin } \\
\text { (orta kuvvette) azalacağını/düşeceğini } \\
\text { göstermektedir. }\end{array}$ \\
\hline $\begin{array}{l}\text { Tuna, \& } \\
\text { Yeşiltaş, } \\
\text { (2014) }\end{array}$ & $\begin{array}{l}\text { Anatolia: } \\
\text { Turizm } \\
\text { Araştırmaları } \\
\text { Dergisi }\end{array}$ & $\begin{array}{l}\text { Etik iklim, İşe } \\
\text { Yabancılaşma ve } \\
\text { Örgütsel Özdeşleşmenin } \\
\text { İşten Ayrılma Niyeti } \\
\text { Üzerindeki Etkisi: Otel } \\
\text { İşletmelerinde Bir } \\
\text { Araştırma }\end{array}$ & Anket & $\begin{array}{l}\text { Etik iklim, işe yabancılaşma ve } \\
\text { örgütsel özdeşleşmenin işten } \\
\text { ayrılma niyeti üzerindeki etkisi } \\
\text { araştırmak. }\end{array}$ & $\begin{array}{l}\text { Etik iklim türleri olan kişisel ahlak ve } \\
\text { kişisel çıkarın yabancılaşma üzerinde, } \\
\text { kişisel çıkarın örgütsel özdeşleşme } \\
\text { üzerinde, özdeşleşmenin ve } \\
\text { yabancılaşmanın işten ayrılma niyeti } \\
\text { üzerinde etkisi olduğu tespit edilmiştir. }\end{array}$ \\
\hline
\end{tabular}




\begin{tabular}{|c|c|c|c|c|c|}
\hline Yazar & Yayın Yeri & Çalışmanın Başlığı & $\begin{array}{l}\text { Veri Toplama } \\
\text { Aracı }\end{array}$ & Amacı & Sonucu \\
\hline $\begin{array}{l}\text { Çelik ve ark., } \\
\text { (2015) }\end{array}$ & $\begin{array}{l}\text { Ege Akademik } \\
\text { Bakış Dergisi }\end{array}$ & $\begin{array}{l}\text { Relationship Between } \\
\text { Ethical Leadership, } \\
\text { Organizational } \\
\text { Commitment and Job } \\
\text { Satisfaction at Hotel } \\
\text { Organizations / Otel } \\
\text { İşletmelerinde Etik } \\
\text { Liderlik, Örgütsel Bağlılık } \\
\text { ve Iş̧ Tatmini Arasındaki } \\
\text { İlişki }\end{array}$ & Anket & $\begin{array}{l}\text { Otel işletmelerinde etik liderlik } \\
\text { tarzını örgütsel bağlılık ve } \\
\text { iş tatmini üzerindeki etkisini } \\
\text { araştırmak ve örgütsel bağlılığın } \\
\text { etik liderlik ve iş tatmini arasındaki } \\
\text { aracılık rolünü ortaya koymak. }\end{array}$ & $\begin{array}{l}\text { Etik liderliğin örgütsel bağ|ılık ve iş } \\
\text { tatmini üzerinde ve örgütsel bağlı̆ığın } \\
\text { iş tatmini üzerinde olumlu etkisi } \\
\text { olduğu ortaya çıkmıştır. }\end{array}$ \\
\hline $\begin{array}{l}\text { Dedeoğlu ve } \\
\text { ark., (2016) }\end{array}$ & $\begin{array}{l}\text { Yönetim ve } \\
\text { Ekonomi } \\
\text { Araştırmaları } \\
\text { Dergisi }\end{array}$ & $\begin{array}{l}\text { Etik Liderlik, Örgütsel } \\
\text { Bağlılık ve İş Tatmini } \\
\text { Arasındaki Ilişkide: } \\
\text { Cinsiyet ve Çalışma } \\
\text { Süresinin Farkılıştırıcı } \\
\text { (Moderate) Rolü }\end{array}$ & Anket & $\begin{array}{l}\text { Etik liderlik, örgütsel bağlıık ve iş } \\
\text { tatmini ilişkisinde cinsiyetin ve } \\
\text { çalışma süresinin farklılaştırıcı } \\
\text { rolünü ortaya koymak }\end{array}$ & $\begin{array}{l}\text { Etik liderliğin örgütsel bağlılık } \\
\text { üzerindeki etkisinde hem cinsiyet hem } \\
\text { de çalışma süresinin farklılaştırıcı rolü } \\
\text { olduğu ve erkeklere göre kadınların } \\
\text { örgütsel bağlılıklarında da etik } \\
\text { liderliğin daha önemli bir faktör olduğu } \\
\text { ve işletmede bir yıl ve daha az süre } \\
\text { çalışanların bir yıldan daha fazla süre } \\
\text { çalışanlara oranla etik liderliğin örgüte } \\
\text { bağlılıkları açısından daha belirleyici } \\
\text { olduğu tespit edilmiştir. }\end{array}$ \\
\hline $\begin{array}{l}\text { Sarı, \& } \\
\text { Doğantekin, } \\
\text { (2016) }\end{array}$ & $\begin{array}{l}\text { İşletme } \\
\text { Araştırmaları } \\
\text { Dergisi }\end{array}$ & $\begin{array}{l}\text { Konaklama } \\
\text { İşletmelerinde Örgütsel } \\
\text { Etik Iklim ve Örgütsel } \\
\text { Sinizm iliş̧kisi Üzerine Bir } \\
\text { Araştırma }\end{array}$ & Anket & $\begin{array}{l}\text { Çalışanların algıladıkları örgütsel } \\
\text { etik iklim ile örgütsel sinizm } \\
\text { düzeyleri arasındaki ilişkileri } \\
\text { belirlemek }\end{array}$ & $\begin{array}{l}\text { Örgütsel etik iklim ile örgütsel sinizm } \\
\text { düzeyleri arasında negatif yönlü } \\
\text { bir iliş̧ki belirlenmiştir. Buna göre } \\
\text { çalışanların algıladıkları etik iklim } \\
\text { düzeyi arttıkça, örgütsel sinizm } \\
\text { düzeylerinin azalacağı söylenebilir. }\end{array}$ \\
\hline $\begin{array}{l}\text { Şahin ve ark., } \\
(2016)\end{array}$ & $\begin{array}{l}\text { Balıkesir } \\
\text { Üniversitesi } \\
\text { Sosyal Bilimler } \\
\text { Enstitüsü } \\
\text { Dergisi }\end{array}$ & $\begin{array}{l}\text { Otel İşletmelerinde } \\
\text { Yöneticilerin Çalışanlara } \\
\text { Karşı Etik Tutumları }\end{array}$ & Anket & $\begin{array}{l}\text { Otel yöneticilerinin çalışanlara } \\
\text { karşı davranışlarının etik açıdan } \\
\text { değerlendirilmesi }\end{array}$ & $\begin{array}{l}\text { Araştırmaya katılan kişilerin eğitim } \\
\text { düzeylerine göre yöneticilerin etik } \\
\text { davranışlarını algılama düzeyinin } \\
\text { farklııı gösterdiği tespit edilmiştir. } \\
\text { Ayrıca yöneticilerin etik davranışları, } \\
\text { çalışanların motivasyonuna ve } \\
\text { verimliliğine büyük ölçüde etki } \\
\text { etmektedir. }\end{array}$ \\
\hline Şentürk, (2014) & $\begin{array}{l}\text { Seyahat ve Otel } \\
\text { İşletmeciliği } \\
\text { Dergisi }\end{array}$ & $\begin{array}{l}\text { Etik Liderliğin } \\
\text { Belirleyicileri Olarak } \\
\text { Kişilik, Örgüt Kültürü ve } \\
\text { Dini Yönelim: Antalya'daki } \\
\text { Dört ve Beş Yıldızlı } \\
\text { Otellerde Bir Uygulama }\end{array}$ & Anket & $\begin{array}{l}\text { Kişilik, örgüt kültürü ve dini } \\
\text { yönelim değişkenlerinin etik } \\
\text { liderlik oluşumundaki etkilerini } \\
\text { belirlemek }\end{array}$ & $\begin{array}{l}\text { Kişilik özelliklerinden uyumluluk ve } \\
\text { açıklık özelliklerinin, örgüt kültürü } \\
\text { tiplerinden klan kültürünün etik liderlik } \\
\text { ile ilişkili olduğu tespit edilmiştir. Dini } \\
\text { yönelim açısından ise hem içsel dini } \\
\text { yönelim hem de dışsal dini yönelimin } \\
\text { etik liderlik ile ilişkili olduğu sonucuna } \\
\text { ulaşılmıştır. }\end{array}$ \\
\hline $\begin{array}{l}\text { Göktas Kulualp, } \\
\text { \& Erol, (2017) }\end{array}$ & $\begin{array}{l}\text { Uluslararası } \\
\text { Sosyal } \\
\text { Araştırmalar } \\
\text { Dergisi }\end{array}$ & $\begin{array}{l}\text { Yöneticilerde Duygusal } \\
\text { Zekanın Etik Liderlik } \\
\text { Davranışı Üzerindeki } \\
\text { Etkisi }\end{array}$ & Anket & $\begin{array}{l}\text { Duygusal zekânın etik liderlik } \\
\text { davranışı üzerindeki etkisini } \\
\text { ölçmek }\end{array}$ & $\begin{array}{l}\text { Duygusal zekanın boyutlarından } \\
\text { olan duygusal benlik bilinci, kendini } \\
\text { gerçekleştirme, gerçeklik, esneklik } \\
\text { ve iyimserlik boyutlarının etik liderlik } \\
\text { davranışı üzerinde istatistiki olarak } \\
\text { anlamlı bir etkisinin olduğu tespit } \\
\text { edilmiştir. }\end{array}$ \\
\hline
\end{tabular}




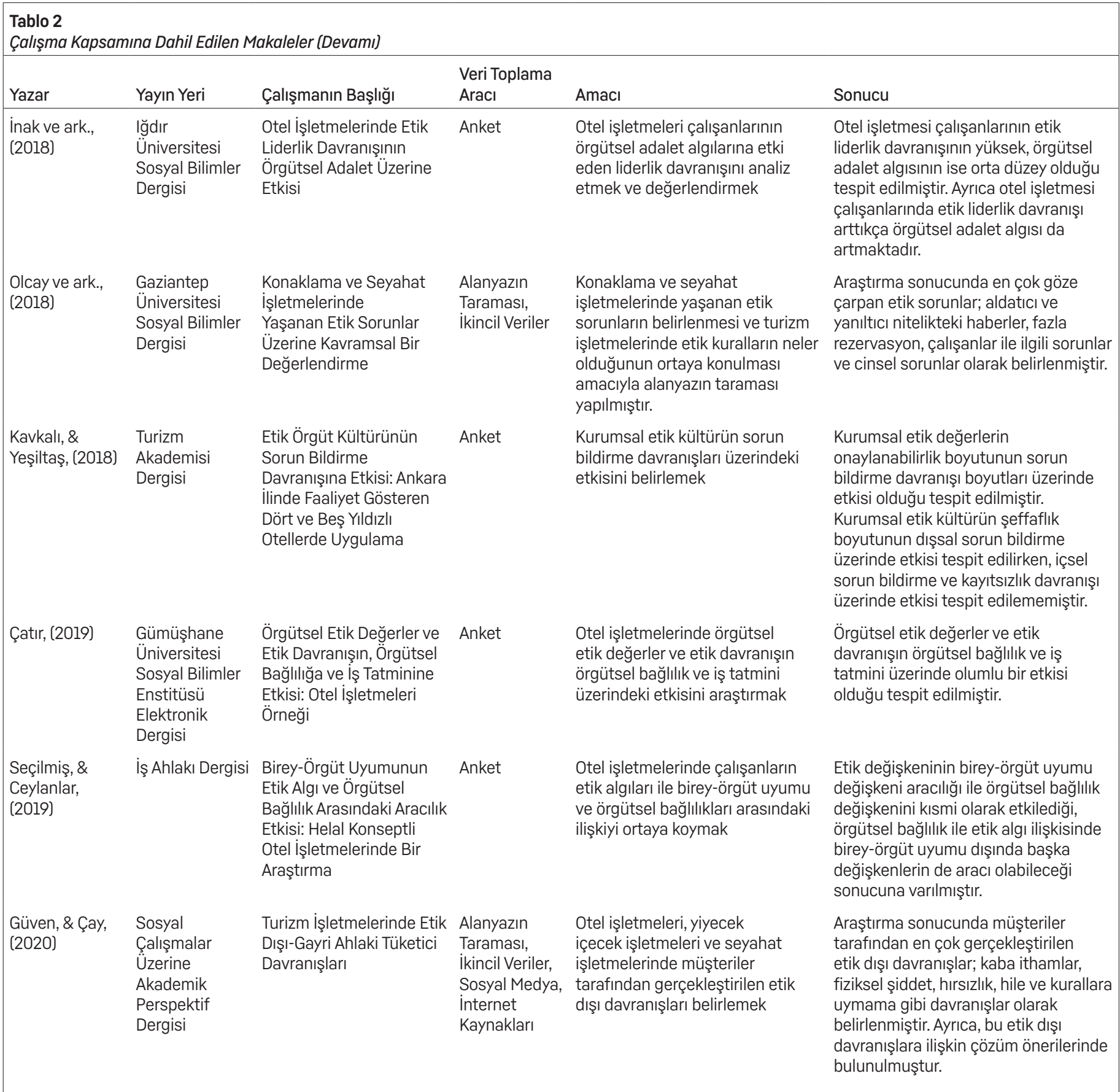

ları, yayınlandığı dergi, yayınlandığı yıl, konusu, yayın bilgisi, örneklem grubu vb.) incelenmesidir (Diodato, 1994; Evren, \& Kozak, 2012; Temizkan ve ark., 2015). Bibliyometrik araştırmalarda elde edilen bulgular, ilgili bilim dalında zaman içerisinde ne kadar gelişme olduğunu ve ne gibi çalışmalar yapıldığını göstermesi açısından yol gösterici niteliktedir. Bu yönüyle, gelecekte yapılacak olan çalışmalar için araştırmacılara öngörü imkânı sağlamaktadır (Oruç, \& Türkay, 2017).

Ulusal alanyazında turizm alanında yapılmış olan bibliyometrik çalışmalarda araştırmacıların genellikle makale, bildiri, lisansüstü tezleri ve dergileri incelediği görülmektedir. Örneğin; Kozak 1999 yılında dünya genelinde turizm alanlarında yayınlanmakta olan akademik dergileri, Evren ve Kozak 2012 yılında Anatolia: Turizm Araştırmaları dergisinde yayınlanmış olan hakem denetimli makaleleri, Tayfun ve ark., 2018 yılında turizm ile ilgili altı anabilim dalında yiyecek içecek alanında yazılmış lisansüstü tezleri, Baytok ve ark., 2019 yılında Ulusal Turizm Kongrelerinde yayınlanmış olan bildirileri incelemiştir. Bu bağlamda çalışmada, "otel işletmelerinde etik konusu" ile ilgili ulusal alanyazınında yayınlanmış olan makale ve tezlerin bibliyometrik parametreler açısından ele alınması amaçlanmıştır. Bu amaç doğrultusunda, ulaşıl- 
mış olan makale ve tezlerin; yoğunlaştığı konular, veri toplama yöntemi, makalelerin yayınlandığı dergi, yayınlandığı yıl, yazar unvanları, tezler için araştırmanın yapıldığı enstitü gibi konulara dikkat çekilerek gelecekte yapılacak olan araştırmalara kaynak niteliğinde olması ve araştırma konusu seçiminde yön verici olması benimsenmiştir.

Araştırmada veri toplama tekniği olarak nitel araştırma yöntemlerinden doküman tarama kullanılarak, 2020 yılı Haziran- Ağustos ayları arasında Google Akademik ve YÖK Ulusal Tez Merkezi sitelerinde "etik", "otel işletmelerinde etik", "turizm" gibi anahtar kelimeler taratılmış ve 2000-2020 yılları arasında yayınlanmış olan makale ve tezlere ulaşılmıştır. Ulaşılan çalışmaların çoğunluğunda araştırmanın örneklemini otel işletmelerindeki işgörenler ve yöneticiler oluşturmaktadır. UlaşıIan çalışmalar arasında az sayıda araştırmanın örneklemini "turizmde eğitim alan öğrencilerin" oluşturduğu makale ve tezler çalışmanın bütünlüğünü bozmaması için araştırma kapsamı dışında tutulmuştur. Örneklemini otel işletmelerindeki işgörenler ve yöneticilerin oluşturduğu araştırmalar dikkate alınmış olup, bu araştırmanın kapsamına 28 adet makale ve 22 adet tez dahil edilmiştir. Turizm alanında daha önce yapılan bibliyometrik çalışmalarda en sık kullanılmış olan ve gelecekteki araştırmalar için yol gösterici niteliğinin yüksek olduğu düşünülen parametreler çalışmada baz alınmıştır. Bu parametreler; "çalışmanın yayınlandığı yıl", "yazar sayısı", "çalışmanın türü", "yazarların bağlı oldukları üniversiteler" ve "yazarların akademik unvanı" şeklindedir.

\section{Otel İşletmelerinde Etik Konulu Ulusal Alanyazında Yayınlanmış Olan Makale Ve Tezler}

YÖK Ulusal Tez Merkezi ve Google Akademik arama motoru tabanlı tarama sonucunda "otel işletmelerinde etik" konulu 2000-2020 yılları arasında ulusal alanyazında yayınlamış olan makale ve tezler Tablo 2 ve Tablo 3'de gösterilmiştir.

\section{Bulgular}

Yapılan taramalar sonucunda, 28 adet makale ve 22 adet tez çalışmasına ulaşılmıştır. Ulaşılan tezlerden sadece 4 tanesi doktora düzeyinde olup, diğer tüm tezler yüksek lisans düzeyinde gerçekleşmiştir.

\section{Ulaşılan Makalelerin Yazar Sayısına Göre Dağılımı}

Şekil l'de otel işletmelerinde etik konusu ile ilgili yazılmış olan makalelerin yazar sayısına göre dağılımı gösterilmiștir. Grafikte de görüldüğü üzere 28 adet makaleden 6'sı tek yazarlı, 14 tanesi 2 yazarlı, 8 tanesi ise 3 ve daha fazla yazarlı çalışmalardır. Ayrıca, ulaşılan makaleler arasında 3 yazarın birden fazla makaleye katkı sağladığı dikkat çekmektedir.

Turizmin disiplinler arası bir endüstri olması sebebiyle, farklı bilim dallarından akademisyenlerin bir araya gelerek ortak çalışmalar yaptıkları görülmektedir. Bu durum, çok yazarlı çalışmaların fazla olmasının sebebi olarak gösterilebilir. Ayrıca, ulaşılan makaleler incelendiğinde birçok çalışmada yüksek lisans öğrencisi ve bilim uzmanı yazarların da yer aldığı görülmektedir. Bu açıdan bakıldığında, deneyimi az olan yazarların daha deneyimli yazarlar ile ortak çalışma içerisinde bulunmak istemelerinde, çalışmanın daha prestijli görülmesi ve yayının kabulü açısından avantaj yaratması gibi düşünceler etkili olabilir. Yine çok yazarlı olan çalışmalarda, yazar sayısının birden fazla olmasının oluşabilecek hataların en aza indirilmesinde önemli bir katkısı olmaktadır.

\section{Ulaşılan Makalelerin Yazar Unvanlarına Göre Dağılımı}

Tablo 4'e göre, araştırmalara en çok katkı sağlayan yazarların \%30,51 oranında Doktora Öğretim Üyesi unvanına sahip yazarlar olduğu görülmektedir. İkinci sırada ise \%22,03 ile Doçent Doktor ve \%16,95 ile üçüncü sırada Öğretim Görevlisi unvanına sahip olan yazarların bulunduğu görülmektedir. Yazarların akademik kariyerleri için yayınlanmış yazılara intiyaç duymaları bunun nedeni olarak görülebilir.
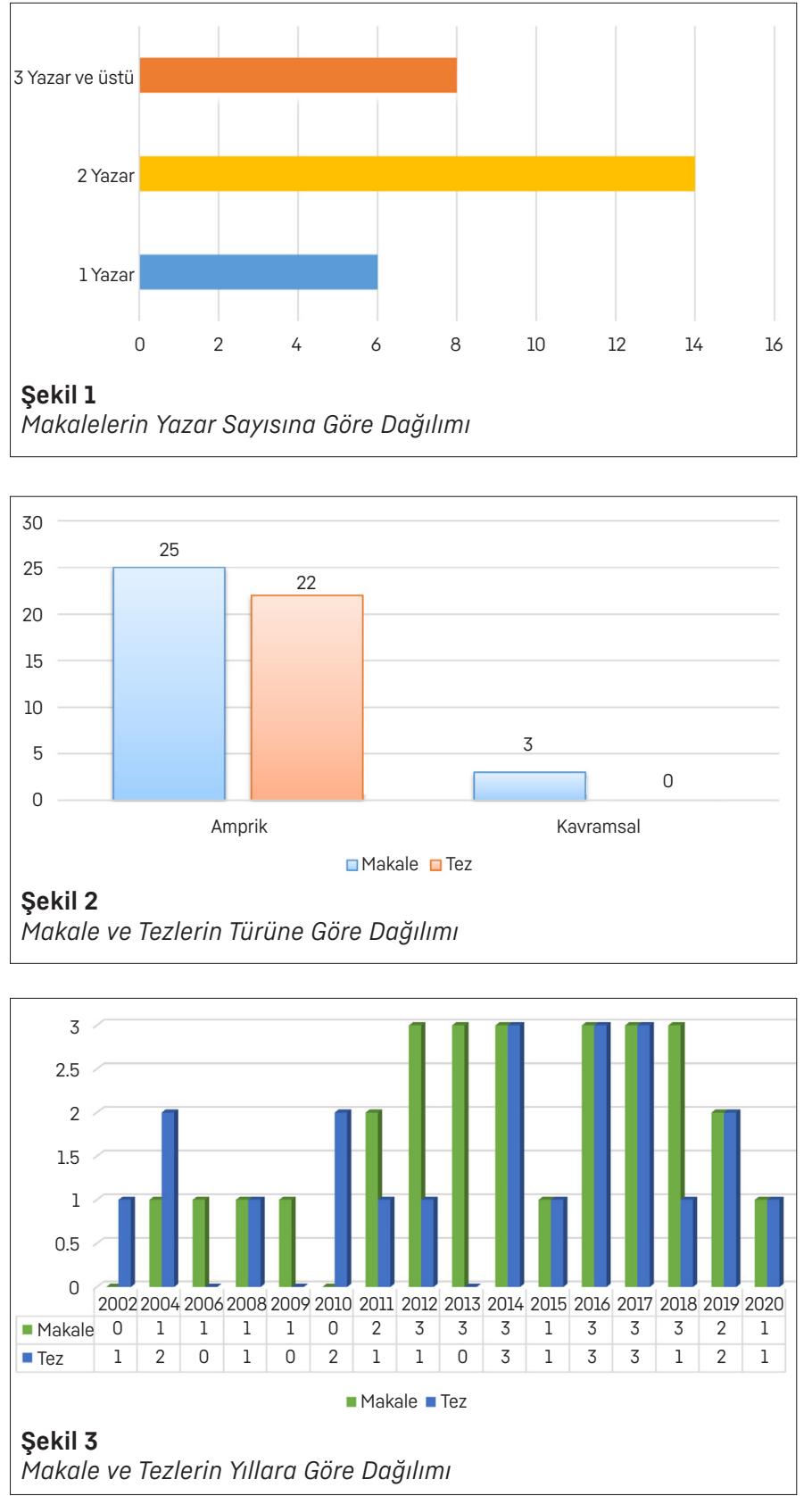

\section{Ulaşılan Makale ve Tezlerin Türüne Göre Dağılımı}

Bir ülkede yapılan çalışmaların ampirik veya kavramsal olması o ülkede yapılan çalışmaların düzeyi hakkında bilgi sahibi olabilmek adına bazı ipuçları sağlayabilmektedir (Kozak, 1994). Bu bağlamda, Şekil 2'de otel işletmelerinde etik konusu ile ilgili yazılmış olan makale ve tezlerin türüne göre dağılımı gösterilmiştir. Şekilde de görüldüğü üzere makale ve tezlerin yüksek çoğunluğu ampirik çalışmalardır. Toplam 28 makaleden 25'i ampirik, kalan 3 tanesi kavramsal çalışmalardır. Tezlerin ise hepsi ampirik çalışmalardır.

Ulaşılan Makale ve Tezlerin Yazıldıkları Yıllara Göre Dağılımı Şekil 3'te otel işletmelerinde etik konulu ulaşılmış olan makale ve tezlerin yayınlandığı yıllara göre dağııımı gösterilmiştir. Yazılan tezlerin 4 tanesi doktora tezi olup kalan 18 tanesi yüksek lisans tezidir. Grafiğe 


\begin{tabular}{|c|c|c|c|c|c|}
\hline Yazar & Enstitü & Çalışmanın Başlığı & $\begin{array}{l}\text { Veri } \\
\text { Toplama } \\
\text { Aracı }\end{array}$ & Amacı & Sonucu \\
\hline $\begin{array}{l}\text { Karakaş, } \\
(2002)\end{array}$ & $\begin{array}{l}\text { Eskişehir Anadolu } \\
\text { Üniversitesi Sosyal } \\
\text { Bilimler Enstitüsü } \\
\text { Turizm Iş̧letmeciliği } \\
\text { Anabilim Dalı }\end{array}$ & $\begin{array}{l}\text { Otel İşletmelerinde } \\
\text { Çalışan Servis } \\
\text { Personelinin Etik } \\
\text { Davranışları Üzerine Bir } \\
\text { Araştırma (YL) }\end{array}$ & Anket & $\begin{array}{l}\text { Otellerin yiyecek içecek } \\
\text { departmanlarında çalışan servis } \\
\text { personelinin bireysel, örgütsel, } \\
\text { yönetsel ve mesleki etik } \\
\text { davranışlarına uyma düzeylerini } \\
\text { belirlemek }\end{array}$ & $\begin{array}{l}\text { Araştırma kapsamındaki servis } \\
\text { personelinin bireysel etik davranışları } \\
\text { incelendiğinde, temel etik değerler ile } \\
\text { ilgili (dürüstlük, sorumluluk sahibi olma, } \\
\text { adalet, sözünde durma gibi) herhangi bir } \\
\text { sıkıntı yaşanmadığı ve personelin örgütsel, } \\
\text { yönetsel ve mesleki etik davranışları için } \\
\text { gerekli altyapılarının mevcut olduğu tespit } \\
\text { edilmiştir. }\end{array}$ \\
\hline $\begin{array}{l}\text { Bayraktar, } \\
(2004)\end{array}$ & $\begin{array}{l}\text { Kocaeli Üniversitesi } \\
\text { Sosyal Bilimler } \\
\text { Üniversitesi İletişim } \\
\text { Anabilim Dalı }\end{array}$ & $\begin{array}{l}\text { Otel İşletmelerinde } \\
\text { Halka Illişkiler } \\
\text { Konseptinin Etik } \\
\text { Değerler Yönünden } \\
\text { İncelenmesi }(Y L)\end{array}$ & Anket & $\begin{array}{l}\text { İstanbul'daki } 5 \text { yıldızlı otel } \\
\text { işletmelerinde halkla ilişkiler } \\
\text { departmanı yöneticilerinin } \\
\text { etik anlayışlarının irdelenmesi, } \\
\text { bireysel ve kurumsal etik } \\
\text { duyarlııklarının halkla ilişkiler } \\
\text { meslek ahlakı kapsamında } \\
\text { değerlendirilmesi }\end{array}$ & $\begin{array}{l}\text { Yapılan değerlendirmelere göre } \\
\text { yöneticilerin görüşlerine ilişkin elde edilen } \\
\text { sonuçlar ile sorulara verdikleri cevaplar } \\
\text { çelişkili olarak görülmüştür. Örneğin; } \\
\text { cinsiyet ile kadının görsel çekiciliği } \\
\text { arasında anlamlı bir ilişki olmadığı } \\
\text { görüşünü paylaşan katılımcı yöneticilerin } \\
\text { çoğunun kadın olması ve işe alımlarda } \\
\text { mesleki etik değerlerin göz ardı edildiği } \\
\text { görülmüştür. }\end{array}$ \\
\hline $\begin{array}{l}\text { Karayiğit, } \\
(2004)\end{array}$ & $\begin{array}{l}\text { Dokuz Eylül Üniversitesi } \\
\text { Sosyal Bilimler } \\
\text { Enstitüsü Turizm } \\
\text { İşletmeciliği Anabilim } \\
\text { Dalı }\end{array}$ & $\begin{array}{l}\text { Beş Yıldızlı Otel } \\
\text { İşletmelerinde } \\
\text { Çalışanların Etik } \\
\text { Davranışları Üzerine } \\
\text { Bir Uygulama (YL) }\end{array}$ & Anket & $\begin{array}{l}\text { Ankara, Izmir ve İstanbul } \\
\text { merkezde bulunan } 5 \\
\text { yıldızı otel işletmelerinde } \\
\text { uygulanan çalışmanın amacı; } \\
\text { çalışanların mesleki açıdan etik } \\
\text { davranışlarını belirlemek }\end{array}$ & $\begin{array}{l}\text { Katılımcıların etik davranışları ile çalıştıkları } \\
\text { bölüm arasında ilişki olduğu saptanmıştır. } \\
\text { Ayrıca etik davranışlar ile çalışılan süre, } \\
\text { öğrenim durumu, medeni durum, cinsiyet, } \\
\text { yaş, kişisel özellikler gibi faktörlerin de } \\
\text { ilişkili olduğu gözlemlenmiştir. }\end{array}$ \\
\hline $\begin{array}{l}\text { Ateş, } \\
\text { (2008) }\end{array}$ & $\begin{array}{l}\text { Dokuz Eylül Üniversitesi } \\
\text { Sosyal Bilimler } \\
\text { Enstitüsü Turizm } \\
\text { İşletmeciliği Anabilim } \\
\text { Dalı }\end{array}$ & $\begin{array}{l}\text { Otel İşletmelerinde } \\
\text { Yöneticilerin İş Etiğine } \\
\text { Yaklaşımları ve İzmir } \\
\text { ilinde Dört ve Beş Yıldızıı } \\
\text { Otel İşletmelerinde Bir } \\
\text { Uygulama (YL) }\end{array}$ & Anket & $\begin{array}{l}\text { Otel işletmelerinin etik } \\
\text { ilkelere bağlılığı ile ekonomik } \\
\text { açıdan varlıklarını devam } \\
\text { ettirebilmeleri arasındaki } \\
\text { ilişkiyi ortaya çıarmak. Ayrıca, } \\
\text { otel yöneticilerinin iş etiğine } \\
\text { yaklaşımlarını, etik kuralları ne } \\
\text { ölçüde dikkate aldıklarını ortaya } \\
\text { koymayı ve bu konuda öneriler } \\
\text { geliştirmek }\end{array}$ & $\begin{array}{l}\text { Otelcilik sektöründeki yöneticilerin etik } \\
\text { kuralları çok fazla dikkate almadığı } \\
\text { gözlemlenmiştir. Ayrıca etik değerlere } \\
\text { bağlıık otel işletmesinin kar kaygısından } \\
\text { etkilenmektedir. }\end{array}$ \\
\hline $\begin{array}{l}\text { Kaplan, } \\
\text { (2010) }\end{array}$ & $\begin{array}{l}\text { Konya Selçuk } \\
\text { Üniversitesi Sosyal } \\
\text { Bilimler Enstitüsü } \\
\text { İşletme Anabilim Dalı }\end{array}$ & $\begin{array}{l}\text { Otel İşletmelerinde } \\
\text { Etiksel İklim ve Örgütsel } \\
\text { Destek Algılamalarının } \\
\text { Örgütsel Bağlılık } \\
\text { Üzerindeki Etkisi: } \\
\text { Kapadokya Örneği (DR) }\end{array}$ & Anket & $\begin{array}{l}\text { Çalışanların etiksel iklim ve } \\
\text { örgütsel destek algılamalarının } \\
\text { örgütsel bağlılıkları üzerindeki } \\
\text { etkisini belirlemek ve } \\
\text { çalışanların demografik } \\
\text { özellikleri ve çalışılan otel } \\
\text { işletmelerinin özelliklerine } \\
\text { göre örgütsel bağlılık düzeyleri } \\
\text { arasında anlamlı farklılıklar olup } \\
\text { olmadığını ortaya koymak }\end{array}$ & $\begin{array}{l}\text { Çalışanların örgütsel destek algılamaları } \\
\text { arttıkça duygusal ve normatif bağlııkları } \\
\text { artarken, devam bağlııklarının azalacağı } \\
\text { tespit edilmiştir. Ayrıca } 5 \text { yıldızlı otellerde } \\
\text { çalışanların duygusal ve devam bağılık } \\
\text { düzeylerinin } 4 \text { yıldızlı otellerde çalışanlara } \\
\text { göre daha yüksek olduğu görülmüştür. }\end{array}$ \\
\hline $\begin{array}{l}\text { Bahadır, } \\
\text { (2010) }\end{array}$ & $\begin{array}{l}\text { Sakarya Üniversitesi } \\
\text { Sosyal Bilimler } \\
\text { Enstitüsü Turizm } \\
\text { İşletmeciliği Anabilim } \\
\text { Dalı }\end{array}$ & $\begin{array}{l}\text { Beş Yıldızlı Otel } \\
\text { İşletmelerinde Etik } \\
\text { Uyygulamaları: İstanbul } \\
\text { Örneği (YL) }\end{array}$ & Anket & $\begin{array}{l}\text { Konaklama işletmelerinde } \\
\text { etik uygulamalar hakkında } \\
\text { değerlendirme yapılarak, } \\
\text { uyulması gereken kurallar } \\
\text { hakkında bir standart } \\
\text { oluşturulmasına katkı sağlamak }\end{array}$ & $\begin{array}{l}\text { Konaklama işletmelerinde çalışanların } \\
\text { etik algılama düzeylerinin kabul edilebilir } \\
\text { düzeyde olduğu, yönetici ve patronların } \\
\text { görüşlerinden etkilendiği ve etik algı } \\
\text { düzeyinde işgören karakter ve kişiliğinin } \\
\text { önemli yeri olduğu sonucuna varılmıştır. }\end{array}$ \\
\hline $\begin{array}{l}\text { Ekiztepe, } \\
\text { (2011) }\end{array}$ & $\begin{array}{l}\text { Muğla Üniversitesi } \\
\text { Sosyal Bilimler } \\
\text { Enstitüsü Turizm } \\
\text { İşletmeciliği Anabilim } \\
\text { Dalı }\end{array}$ & $\begin{array}{l}\text { Konaklama } \\
\text { İşletmelerinde Etik } \\
\text { İklimi, Örgütsel Adalet } \\
\text { ve Örgütsel Bağllık } \\
\text { iliş̧isi (YL) }\end{array}$ & Anket & $\begin{array}{l}4 \text { ve } 5 \text { yıldızlı konaklama } \\
\text { işletmelerinde etik iklimin } \\
\text { işgörenlerin adalet algılarına } \\
\text { bağlı olarak örgütsel bağlıık } \\
\text { düzeyleri üzerindeki etkisini } \\
\text { belirlemek. }\end{array}$ & $\begin{array}{l}\text { Çalışanların algıladıkları etik örgüt iklimi ile } \\
\text { örgütsel adalet uygulamalarının, çalışanın } \\
\text { örgüte yönelik tutumları üzerinde etkili } \\
\text { olduğu sonucu ortaya çıkmıştır. }\end{array}$ \\
\hline
\end{tabular}




\begin{tabular}{|c|c|c|c|c|c|}
\hline Yazar & Enstitü & Çalışmanın Başlığı & $\begin{array}{l}\text { Veri } \\
\text { Toplama } \\
\text { Aracı }\end{array}$ & Amacı & Sonucu \\
\hline $\begin{array}{l}\text { Yeşiltaş, } \\
\text { (2012) }\end{array}$ & $\begin{array}{l}\text { Gazi Üniversitesi Eğitim } \\
\text { Bilimleri Enstitüsü } \\
\text { Turizm İşletmeciliği } \\
\text { Eğitimi Anabilim Dalı }\end{array}$ & $\begin{array}{l}\text { Örgütsel } \\
\text { Özdeşleşmenin } \\
\text { Oluşmasında } \\
\text { Belirleyiciler Olarak } \\
\text { Etik Liderlik ve Etik } \\
\text { İklim: Otel İşletmelerine } \\
\text { Yönelik Bir Uygulama } \\
\text { (DR) }\end{array}$ & Anket & $\begin{array}{l}\text { Bireylerin örgütleriyle } \\
\text { özdeşleşmelerinde etik liderliğin } \\
\text { ve örgütün genel etik ikliminin } \\
\text { etkili olup olmadığını araştırmak }\end{array}$ & $\begin{array}{l}\text { Etik liderliğin etik iklim ve örgütsel } \\
\text { özdeşleşme üzerinde, ayrıca etik iklimin de } \\
\text { örgütsel özdeşleşme üzerinde etkili olduğu } \\
\text { sonucuna ulaşılmıştır. }\end{array}$ \\
\hline $\begin{array}{l}\text { Karadut, } \\
\text { (2014) }\end{array}$ & $\begin{array}{l}\text { Bahçeşehir Üniversitesi } \\
\text { Sosyal Bilimler } \\
\text { Enstitüsü İnsan } \\
\text { Kaynakları Başkanlığı }\end{array}$ & $\begin{array}{l}\text { Etik İklimin ve Örgütsel } \\
\text { Adalet Algılarının } \\
\text { Çalışanların Iş Tatminine } \\
\text { Etkisi: Konaklama } \\
\text { Iş̧letmelerinde Ampirik } \\
\text { Bir Uygulama (YL) }\end{array}$ & Anket & $\begin{array}{l}\text { Örgütsel etik iklimin ve örgütsel } \\
\text { adalet algısı boyutlarının } \\
\text { konaklama işletmeleri } \\
\text { çalışanlarının iş tatmini } \\
\text { üzerindeki etkilerini incelemek }\end{array}$ & $\begin{array}{l}\text { Örgütsel adalet boyutlarının (dağıtımsal } \\
\text { adalet, prosedürel adalet) çalışanların iş } \\
\text { tatmin düzeylerinde önemli etkisi olduğu } \\
\text { sonucu ortaya çıkmıştır. Etik iklim algısının } \\
\text { ise iş tatminini istatistiksel olarak anlamlı } \\
\text { bir şekilde etkilemediği tespit edilmiştir. }\end{array}$ \\
\hline $\begin{array}{l}\text { Şentürk, } \\
\text { (2014) }\end{array}$ & $\begin{array}{l}\text { Akdeniz Üniversitesi } \\
\text { Sosyal Bilimler } \\
\text { Enstitüsü Turizm } \\
\text { İşletmeciliği ve Otelcilik } \\
\text { Anabilim Dalı }\end{array}$ & $\begin{array}{l}\text { Etik Liderliğin } \\
\text { Belirleyicileri Olarak } \\
\text { Kişilik, Örgüt Kültürü, } \\
\text { Dini Yönelim ve Çevresel } \\
\text { Faktörler: Antalya'daki } \\
\text { Dört ve Beş Yıldılıl } \\
\text { Otellerde Bir Uygulama } \\
\text { (DR) }\end{array}$ & Anket & $\begin{array}{l}\text { Bir liderin davranışlarını kişilik, } \\
\text { örgüt kültürü, dini yönelim, } \\
\text { aile çevresi, iş çevresi, sosyal } \\
\text { çevresi, bireysel ve kurumsal } \\
\text { özellikler gibi değişkenler } \\
\text { açısından ele alarak etik bir } \\
\text { liderin gelişiminde önemli olan } \\
\text { faktörleri ortaya çıkarmak }\end{array}$ & $\begin{array}{l}\text { Araştırma kapsamında ele alınan tüm } \\
\text { değişkenlerin etik liderlik oluşumunda } \\
\text { kısmen etki sahibi olduğu tespit edilmiştir. }\end{array}$ \\
\hline $\begin{array}{l}\text { Çalkın, } \\
\text { (2014) }\end{array}$ & $\begin{array}{l}\text { Mustafa Kemal } \\
\text { Üniversitesi Sosyal } \\
\text { Bilimler Enstitüsü } \\
\text { Turizm İşletmeciliği } \\
\text { Anabilim Dalı }\end{array}$ & $\begin{array}{l}\text { Otel Çalışanlarının } \\
\text { Etik Lider Algılaması, } \\
\text { Örgütsel Bağlııı, İşten } \\
\text { Ayrılma Niyeti ve İş } \\
\text { Tatminiyle Demografik } \\
\text { ve İstihdam Özellikleri } \\
\text { Arasındaki Illişki (YL) }\end{array}$ & Anket & $\begin{array}{l}\text { Otel işletmelerinde çalışan } \\
\text { işgörenlerin demografik ve } \\
\text { istihdam özellikleriyle etik } \\
\text { liderlik algılaması, örgütsel } \\
\text { bağlılık, işten ayrılma niyeti } \\
\text { ve iş tatmini arasındaki ilişkiyi } \\
\text { incelemek }\end{array}$ & $\begin{array}{l}\text { İşgörenlerin etik liderlik algılaması, } \\
\text { örgütsel bağlılık, işten ayrılma niyeti } \\
\text { ve iş tatminiyle demografik özellikleri } \\
\text { (yaş, cinsiyet, eğitim durumu, aylık gelir) } \\
\text { ve istihdam özellikleri (çalışılan bölüm, } \\
\text { sektörde çalışılan süre, otelde çalışılan } \\
\text { süre, kadro türü, otelin bulunduğu } \\
\text { il) arasında kısmen anlamlı farklıık } \\
\text { bulunmuştur. }\end{array}$ \\
\hline $\begin{array}{l}\text { Ulutaş, } \\
\text { (2015) }\end{array}$ & $\begin{array}{l}\text { Nevşehir Hacı Bektaş } \\
\text { Veli Üniversitesi Sosyal } \\
\text { Bilimler Enstitüsü } \\
\text { İşletme Anabilim Dalı }\end{array}$ & $\begin{array}{l}\text { Otel İşletmelerinde Etik } \\
\text { İklim Algılamalarının } \\
\text { ve Duygusal Emeğin } \\
\text { Tükenmişlik Üzerine } \\
\text { Etkileri: Nevşehir Örneği } \\
\text { (YL) }\end{array}$ & Anket & $\begin{array}{l}\text { İşgörenlerin etik iklim } \\
\text { algılamalarının ve duygusal } \\
\text { emek davranışlarının } \\
\text { tükenmişlik üzerindeki etkisini } \\
\text { belirlemek }\end{array}$ & $\begin{array}{l}\text { Tükenmişliğin duygusal tükenme ve } \\
\text { kişisel başarı hissi boyutlarını etik iklim } \\
\text { algılamalarının ve derin davranışın } \\
\text { etkilediği, duyarsızlaşma boyutunu ise } \\
\text { derin davranış ve yüzeysel davranışın } \\
\text { etkilediği tespit edilmiştir. }\end{array}$ \\
\hline $\begin{array}{l}\text { Doğantekin, } \\
\text { (2016) }\end{array}$ & $\begin{array}{l}\text { Eskişehir Osmangazi } \\
\text { Üniversitesi Sosyal } \\
\text { Bilimler Enstitüsü } \\
\text { Turizm İşletmeciliği } \\
\text { Anabilim Dalı }\end{array}$ & $\begin{array}{l}\text { Örgütsel Etik Iklim } \\
\text { ve Örgütsel Sinizm } \\
\text { iliş̧kisinin Belirlenmesi: } \\
\text { Konaklama } \\
\text { İşletmelerinde Bir } \\
\text { Uygulama (YL) }\end{array}$ & Anket & $\begin{array}{l}\text { İstanbul ilindeki dört ve beş } \\
\text { yıldızlı konaklama işletmeleri } \\
\text { çalışanlarının algıladıkları } \\
\text { örgütsel etik iklim ile örgütsel } \\
\text { sinizm düzeyleri arasındaki } \\
\text { ilişkileri belirlemek }\end{array}$ & $\begin{array}{l}\text { Örgütsel etik iklim ile örgütsel sinizm } \\
\text { arasında negatif yönlü ve istatistiksel } \\
\text { açıdan anlamlı bir ilişki saptanmıştır. }\end{array}$ \\
\hline $\begin{array}{l}\text { Doğan, } \\
\text { (2016) }\end{array}$ & $\begin{array}{l}\text { Nevşehir Hacı Bektaş } \\
\text { Veli Üniversitesi Sosyal } \\
\text { Bilimler Enstitüsü } \\
\text { İşletme Anabilim Dalı }\end{array}$ & $\begin{array}{l}\text { İş Görenlerde Etik } \\
\text { Tutum ve Davranışların } \\
\text { Oluşmasında Örgütsel } \\
\text { Vatandaşlığın } \\
\text { Rolü: Konaklama } \\
\text { İşletmelerinde Bir } \\
\text { Uygulama (YL) }\end{array}$ & Anket & $\begin{array}{l}\text { Nevşehir ilinde faaliyet gösteren } \\
\text { üç, dört ve beş yıldızlı konaklama } \\
\text { işletmelerinde istihdam edilen } \\
\text { iş görenlere ilişkin etik tutum } \\
\text { ve davranışların ölçülmesi ve } \\
\text { örgütsel vatandaşlığa ne derece } \\
\text { etkisinin olduğunun belirlenmesi }\end{array}$ & $\begin{array}{l}\text { Araştırma örneklemini oluşturan } \\
\text { konaklama işletmelerindeki işgörenlerin } \\
\text { etik tutum ve davranışları ile örgütsel } \\
\text { vatandaşlık davranışı arasında pozitif } \\
\text { yönlü ve anlamlı bir ilişki bulunmuştur. Yani } \\
\text { iş görenlerin örgütsel vatandaşlık düzeyi } \\
\text { arttıkça etik tutum ve davranışlarının da } \\
\text { artacağı anlaşımaktadır. }\end{array}$ \\
\hline İnak, (2016) & $\begin{array}{l}\text { Nevşehir Hacı Bektaş } \\
\text { Veli Üniversitesi Sosyal } \\
\text { Bilimler Enstitüsü } \\
\text { İşletme Anabilim Dalı }\end{array}$ & $\begin{array}{l}\text { Etik Liderlik } \\
\text { Davranı̧ının Örgütsel } \\
\text { Adalet Üzerine Etkisi } \\
(Y L)\end{array}$ & $\begin{array}{l}\text { Anket, } \\
\text { Yüz Yüze } \\
\text { Görüşme }\end{array}$ & $\begin{array}{l}\text { Etik liderlik davranışının örgütsel } \\
\text { adalet üzerine olan etkisini } \\
\text { ortaya çıkartmak }\end{array}$ & $\begin{array}{l}\text { Otel işletmesi çalışanlarının yöneticileri } \\
\text { tarafından sergilenen etik liderlik davranışı } \\
\text { arttıkça örgütsel adalet algılarının da buna } \\
\text { bağlı olarak arttığı tespit edilmiştir. }\end{array}$ \\
\hline
\end{tabular}




\begin{tabular}{|c|c|c|c|c|c|}
\hline Yazar & Enstitü & Çalışmanın Başlığı & $\begin{array}{l}\text { Veri } \\
\text { Toplama } \\
\text { Aracı }\end{array}$ & Amacı & Sonucu \\
\hline $\begin{array}{l}\text { Ceylanlar, } \\
\text { (2017) }\end{array}$ & $\begin{array}{l}\text { Eskişehir Osmangazi } \\
\text { Üniversitesi Sosyal } \\
\text { Bilimler Enstitüsü } \\
\text { Turizm İşletmeciliği } \\
\text { Anabilim Dalı }\end{array}$ & $\begin{array}{l}\text { Helal Konseptli } \\
\text { Otel İşletmelerinde } \\
\text { Çalışanların Etik Algıları, } \\
\text { Birey-Örgüt Uyumu ve } \\
\text { Örgütsel Bağlılıkları } \\
\text { Arasındaki Illişkinin } \\
\text { İncelenmesi (YL) }\end{array}$ & Anket & $\begin{array}{l}\text { Türkiye'deki farklı illerde faaliyet } \\
\text { gösteren helal turizm konseptli } \\
\text { otel işletmelerinde çalışanların } \\
\text { etik algıları, birey-örgüt } \\
\text { uyumu ve örgütsel bağlııkları } \\
\text { arasındaki ilişkilerin belirlenmesi }\end{array}$ & $\begin{array}{l}\text { Helal konseptli otellerde çalışan katılımcı } \\
\text { işgörenlerin öncelikli iş tercihi olduğu } \\
\text { görülmüştür. Ayrıca çalışanların etik algı } \\
\text { düzeylerinin yüksek olduğu, bireysel } \\
\text { değerleri ile örgüt değerlerinin uyumlu } \\
\text { olduğu belirlenmiş̧ir. }\end{array}$ \\
\hline Erol, (2017) & $\begin{array}{l}\text { Karabük Üniversitesi } \\
\text { Sosyal Bilimler } \\
\text { Enstitüsü Turizm } \\
\text { İşletmeciliği Anabilim } \\
\text { Dalı }\end{array}$ & $\begin{array}{l}\text { Duygusal Zekanın } \\
\text { Etik Liderlik Davranışı } \\
\text { Üzerindeki Etkisi: Turizm } \\
\text { Isşletmeleri Yöneticileri } \\
\text { Üzerine Bir Araştırma } \\
\text { (YL) }\end{array}$ & Anket & $\begin{array}{l}\text { Turizm işletmelerinde görevli } \\
\text { yöneticilerin duygusal zekâ } \\
\text { düzeylerinin etik liderlik } \\
\text { davranışları üzerindeki etkisinin } \\
\text { belirlemek }\end{array}$ & $\begin{array}{l}\text { Kişinin yaşı, yöneticilik deneyimi ve } \\
\text { yöneticilik düzeyi arttıkça algılaması da } \\
\text { artmakta ve duygusal anlamda kendi } \\
\text { duygularını ve başkalarının duygularını } \\
\text { sezme ve bu duygularını anlama, } \\
\text { kontrol altına alma konusunda yetenekli } \\
\text { olmaktadır. Ayrıca kişinin deneyimi } \\
\text { arttıkça deneyimlerinden elde ettikleri } \\
\text { yeterliliklere bağlı olarak hem etik davranış } \\
\text { sergileyebilmekte hem de duygusal zekâ } \\
\text { yeteneğine sahip olabilmektedir. }\end{array}$ \\
\hline $\begin{array}{l}\text { Akbaba, } \\
\text { (2017) }\end{array}$ & $\begin{array}{l}\text { Osmaniye Korkut Ata } \\
\text { Üniversitesi Sosyal } \\
\text { Bilimler Enstitüsü } \\
\text { İşletme Anabilim Dalı }\end{array}$ & $\begin{array}{l}\text { Etik Liderlik Algısının } \\
\text { Psikolojik Kontrat İhlali } \\
\text { ve Örgütsel Özdeşleşme } \\
\text { Üzerine Etkisi: Turizm } \\
\text { Sektöründe Bir } \\
\text { Araştırma (DR) }\end{array}$ & Anket & $\begin{array}{l}\text { Turizm sektöründe etik liderlik } \\
\text { algısının psikolojik kontrat ihlali } \\
\text { ve örgütsel özdeşleşme üzerine } \\
\text { etkisinin belirlenmesi }\end{array}$ & $\begin{array}{l}\text { Örneklemi oluşturan iş görenlerin } \\
\text { iletişimsel, iklimsel, örgütsel karar vermede } \\
\text { ve davranışsal etik algılarındaki bir birimlik } \\
\text { artış, örgütsel özdeşleşme üzerinde artış } \\
\text { sağladığı sonucuna ulaşılmıştır. }\end{array}$ \\
\hline $\begin{array}{l}\text { Kavkalı, } \\
\text { (2018) }\end{array}$ & $\begin{array}{l}\text { Mehmet Akif Ersoy } \\
\text { Üniversitesi Sosyal } \\
\text { Bilimler Enstitüsü } \\
\text { İşletme Anabilim Dalı }\end{array}$ & $\begin{array}{l}\text { Etik Örgüt Kültürünün } \\
\text { Sorun Bildirme } \\
\text { Davranışına Etkisi } \\
\text { Ankara Illinde Faaliyet } \\
\text { Gösteren Dört ve } \\
\text { Beş Yıldızlı Otellerde } \\
\text { Uygulama (YL) }\end{array}$ & Anket & $\begin{array}{l}\text { Etik örgüt kültürünün sorun } \\
\text { bildirme davranışı üzerindeki } \\
\text { etkisini belirlemek }\end{array}$ & $\begin{array}{l}\text { İşgörenlerin algıladığı etik örgüt } \\
\text { kültürünün sorun bildirme davranışını } \\
\text { etkilediği tespit edilmiştir. Ayrıca, etik örgüt } \\
\text { kültürünün alt boyutu olan onaylanabilirlik } \\
\text { boyutunun sorun bildirme davranışının alt } \\
\text { boyutları olan içsel sorun bildirme, dışsal } \\
\text { sorun bildirme ve kayıtsızlık boyutlarını } \\
\text { etkilediği belirlenmiştir. }\end{array}$ \\
\hline $\begin{array}{l}\text { Akburak, } \\
\text { (2019) }\end{array}$ & $\begin{array}{l}\text { Nevşehir Hacıbektaş } \\
\text { Veli Üniversitesi, Sosyal } \\
\text { Bilimler Enstitüsü } \\
\text { Turizm Iş̧letmeciliği Ana } \\
\text { Bilim Dalı }\end{array}$ & $\begin{array}{l}\text { Özel Konaklama } \\
\text { Tesislerinde Algılanan } \\
\text { Etik İklimin İş Tatmini } \\
\text { ve İş Performansı } \\
\text { Üzerindeki Etkisi: } \\
\text { Nevşehir Illinde Bir } \\
\text { Araştırma (YL) }\end{array}$ & Anket & $\begin{array}{l}\text { Algılanan etik iklimin iş tatmini } \\
\text { ve iş performansı üzerindeki } \\
\text { etkisinin incelenmesi }\end{array}$ & $\begin{array}{l}\text { Önemseme, kurallar ve bağımsızlık } \\
\text { iklimlerinin iş tatmini arasında pozitif yönlü } \\
\text { ve anlamlı bir ilişkisi olduğu ancak araççılık } \\
\text { ve kanun ve kodlar iklimleri ile anlamılı bir } \\
\text { ilişkisinin olmadığı tespit edilmiştir. }\end{array}$ \\
\hline Özer, (2020) & $\begin{array}{l}\text { İskenderun Teknik } \\
\text { Üniversitesi Sosyal } \\
\text { Bilimler Enstitüsü } \\
\text { Turizm ve Otel } \\
\text { Işletmeciliği Anabilim } \\
\text { Dalı }\end{array}$ & $\begin{array}{l}\text { Algılanan Nepotizmin } \\
\text { Etik Liderlik Aracılığında } \\
\text { Örgütsel Bağlılığa Etkisi: } \\
\text { Otel Isşletmelerinde } \\
\text { Araşırma (YL) }\end{array}$ & Anket & $\begin{array}{l}\text { Isşgörenlerin nepotizm ve etik } \\
\text { liderlik algılamalarının örgütsel } \\
\text { bağlılığın alt boyutlarından } \\
\text { duygusal, devam ve normatif } \\
\text { bağlııı üzerindeki etkisini tespit } \\
\text { etmek }\end{array}$ & $\begin{array}{l}\text { Nepotizmin duygusal bağ|ııık, devam } \\
\text { bağlıı̆ı ve normatif bağlıık üzerinde } \\
\text { anlamlı ve negatif yönlü bir etkisinin } \\
\text { olduğu tespit edilmiştir. }\end{array}$ \\
\hline
\end{tabular}


Tablo 4

Makale Yazarlarının Akademik Unvanına Göre Dağııımı

\begin{tabular}{|lcc|}
\hline Yazar Unvanı & Yazar Sayısı & Toplam Oran \% \\
\hline Arş. Gör. & 3 & 5,08 \\
Öğr. Gör. & 10 & 16,95 \\
Dr. Öğr. Üyesi (Yrd. & 18 & 30,51 \\
Doç. Dr.) & 13 & \\
Doç. Dr. & 2 & 22,03 \\
Prof. Dr. & 9 & 3,39 \\
Öğrenci (Lisansüstü) & 4 & 15,25 \\
Bilim Uzmanı & 59 & 6,78 \\
Toplam & & 100,00 \\
\hline
\end{tabular}

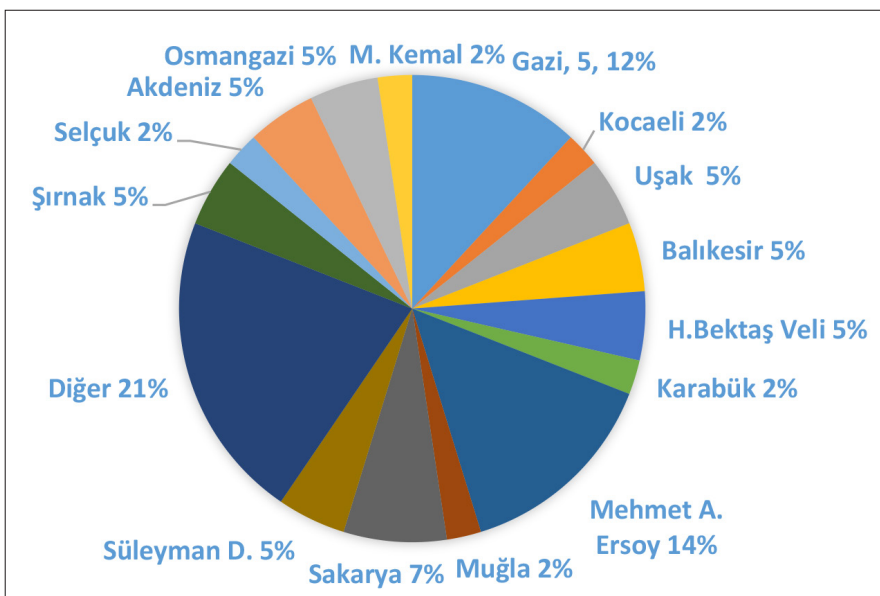

Şekil 4

Yazarların Çalıştığı Kurumlar (Makale)

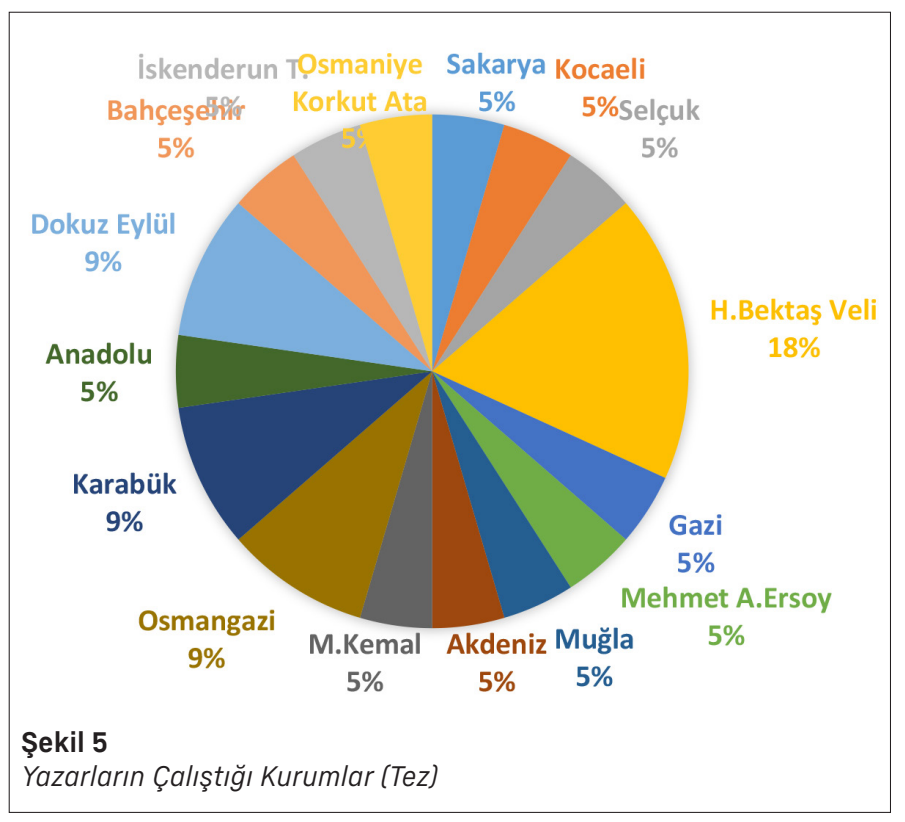

bakıldığında en çok çalışmanın 2014-2016 ve 2017 yıllarında yapıldığı görülmektedir. Ayrıca, son yıllarda bu konu ile ilgili yapılmış çalışmaların giderek arttığı görülmektedir. Turizm sektörünün ülkemiz için önemli bir döviz kaynağı olması sebebiyle artan bir rekabet durumu söz konusudur. Dolayısıyla turizm işletmelerinin yönetiminde benimsemiş olduğu etik uygulamaların önemi de artmıştır. Çünkü, turizm işletmelerinde etik kuralların yerine getirilmesi çalışanların memnuniyetiyle birlikte müşteri memnuniyetini de arttırmaktadır. Turizm sektöründe özellikle otel işletmelerinde etik kuralların bu denli önemli hale gelmesinin araştırmacıları bu konuyu incelemeye yönlendirdiği söylenebilir.

Ulaşılan makalelerden 3 tanesi doktora tezinden, 3 tanesi ise yüksek lisans tezinden faydalanılarak hazırlanmıştır. Ayrıca, Mayıs 2018'de Gaziantep'te düzenlenmiş olan "Uluslararası Etik Araştırmaları Sempozyumu" nedeniyle, 2018 yılında otel işletmelerinde etik konusu ile ilgili yazılmış bildirilere ulaşılmıştır. Olcay ve ark. (2018) tarafından yazılmış olan "Konaklama ve Seyahat işletmelerinde Yaşanan Etik Sorunlar Üzerine Kavramsal Bir Değerlendirme" isimli makale de bu sempozyumda sunulan bildirilerden biridir ve makaleye dönüştürülmüştür. Araştırma sınırlııkları dışında kaldığı için sempozyumdaki diğer bildiler bu çalışmaya dahil edilmemiştir.

\section{Ulaşılan Makale ve Tez Yazarlarının Bağlı Oldukları Kurumlara Göre Dağılımı}

Şekil 4 ve 5'te otel işletmelerinde etik konusu içeren makale ve tezlerin yazarlarının bağlı oldukları üniversitelere göre dağııımı gösterilmiştir. Makalelere ait grafikte bulunan "diğer" kategorisi kapsamında "Erciyes, Cumhuriyet, Afyon Kocatepe, Çukurova, Düzce, Iğdır, Gaziantep Üniversiteleri ile birlikte Anadolu Bil MYO ve Bahçeşehir Mesleki Eğitim Merkezi bulunmaktadır. IIlgili kurumlara ait l'er çalışma bulunmaktadır. Sadece makale türünde bakıldığında en fazla çalışma Gazi ve Mehmet Akif Ersoy Üniversitelerinde gerçekleşirken tez türünde ise ilk sırada Hacı Bektaş Veli Üniversitesi yer almaktadır. Genel olarak makaleler bazında incelendiğinde, farklı üniversitelerden akademisyenlerin bir araya gelerek iş birliği içerisinde olduğu çalışmalar olsa da üniversitelerin daha çok kendi içlerinde iş birliğine gittiği çalışmaların sayısının fazla olduğu görülmektedir.

\section{Tartışma, Sonuç ve Öneriler}

Günümüz otel işletmelerinde yaşanan ayrımcılık, adam kayırma, rüşvet, yolsuzluk, bencillik, hakaret, adaletsizlik, taciz, görevi kötüye kullanma vb. davranışlar etik yaklaşımın ön plana çıkmasına ve daha fazla tartışımasına neden olmuştur. Örgütsel ve bireysel düzeyde yaşanan etik dışı davranışlar da akademisyenler ve araştırmacıları bu konuyu incelemeye itmiştir.

Günümüzde işletmeler arası artan rekabet ortamında rakiplere karşı güçlü olabilmenin en önemli koşullarından biri de örgüt içinde etik ortam yaratabilmektir. Sadece yöneticilerin etik değerlere sahip olması değil, yöneticinin işletmeyi yönetirken etik tutum ve davranışlar sergilemesi, çalışanlara karşı adaletli ve dürüst olması da gerekmektedir. Otel işletmeleri emek yoğun bir hizmet sektörüdür ve insan unsuru ön plandadır. Bu nedenle otel işletmelerinde etik olmayan uygulamalara çok sık rastlamak mümkündür.

Araştırmada, "otel işletmelerinde etik" konulu 2000-2020 yılları arasında ulusal alanyazında yayınlanmış olan çalışmalar (yayınlanmış makale ve tezler) tespit edilmiş olup, ilgili çalışmalar; belirli bibliyometrik parametreler açısından incelenmiştir. Bu anlamda çalışma, otel işletmelerinde etik konusu ile ilgili yapılmış olan çalışmaları ön plana çıkararak ilgili alan yazının durumu hakkında değerlendirme yapma imkânı sunmaktadır. Bu bağlamda, otel işletmelerinde etik konusu ile ilgili yapılan çalışmaların 2010 yılı itibariyle artış gösterdiği tespit edilmiştir. Boğan ve ark. (2018) tarafında yapmış olan bibliyometrik çalışmada da turizm 
yazınında kurumsal sosyal sorumluluk ile ilgili yapılan çalışmaların sayısının 2015 yılı itibariyle artış gösterdiği tespit edilmiştir. Aynı şekilde, Baytok ve ark. (2019) tarafından yapılan çalışmada Ulusal Turizm Kongrelerinde yayınlanan etik ve sosyal sorumluluk konulu bildirilerin sayısının son yıllarda artış gösterdiği tespit edilmiştir. Alan yazındaki benzer nitelikteki çalışmalara bakıldığında eser sayısının sürekli artış gösterdiği görülmektedir. Günümüzde, etik kavramının otel işletmeleri için rekabet unsuru olarak büyük önem taşıması araştırmacıların bu konuya olan ilgilerinin artmasına gerekçe olarak gösterilebilir. UlaşıIan makalelerin yazar sayısına göre bakıldığında ise birden fazla yazarlı makalelerin çoğunlukta olduğu tespit edilmiştir. Yapılan benzer çalışmalara bakıldığında da aynı sonuca ulaşıldığı görülmektedir (Baytok ve ark., 2019; Boğan ve ark., 2018; Çiçek, \& Kozak, 2012). Turizmin disiplinler arası bir endüstri olması nedeniyle farklı bilim dallarından araştırmacıların bir araya gelerek çalışmalarının olası olması bu durumun nedenlerinden biri olarak görülebilir. Ayrıca birden fazla yazarın birlikte çalışmalarının bireylerin farklı bakış açılarıyla düşünmesini sağlaması, gözden kaçabilecek hataların aza indirilmesi gibi avantajları olabilmektedir. Aynı zamanda, deneyimi az olan araştırmacıların çok sayıda yayına sahip olan akademisyenler ile iş birliği içinde olmaları daha nitelikli yayınların ortaya çıkmasını sağlayabilmektedir.

Ulaşılan çalışmalarda, örneklem olarak yöneticiler ve çalışanlar üzerine yoğunlaşımış, ancak turizm sektöründen hizmet alan tüketicilerin etik dışı davranışlarına yönelik çok fazla çalışma olmadığı görülmüştür. Ayrıca örneklem olarak turizm öğrencilerinin seçilmiş olduğu çalışma sayısının da kısıtlı sayıda olduğu gözlemlenmiştir. Bu çalışmalardan Kaya ve Maksudunov (2017) çalışmasının örneklemini her yıl yaz dönemlerini Antalya'da staj uygulaması görerek geçiren Kırgızistan-Türkiye Manas Üniversitesi öğrencileri oluşturmaktadır. Olcay ve Sürme'nin (2015) yapmış olduğu çalışmanın örneklemini turizm işletmelerinde staj eğitimi almış/çalışmış öğrenciler oluşturmaktadır. Pelit ve Arslantürk (2011) tarafından yapılan çalışmanın örneklemi ise turizm eğitimi alan ancak sektörde tecrübesi olan ve olmayan öğrenciler oluşturmaktadır. Çalışmanın bütünlüğünü bozmaması açısından örneklemini öğrencilerin oluşturduğu bu çalışmalar araştırma kapsamı dışında bırakılmıştır.

Bu çalışmanın sektörde yer alan işletmeler için de yol gösterici olduğu düşünülmektedir. Son yıllarda hızla büyüyen ve insan ilişkilerinin üst seviyede olduğu turizm sektöründe, işletmelerin başarıya ulaşabilmeleri ve rakiplerinin önüne geçebilmeleri için etik ilkelere uygun yönetim anlayışı benimsemeleri gerekmektedir. Özellikle çalışanlar açısından değerlendirildiğinde; çalışma saatlerinin uzun olması, alınan maaşın düşük olması, fazla mesai ücretlerinin ödenmemesi, personel konaklama imkânlarında yaşanan sıkıntılar, yöneticilerin etik olmayan davranışları (ayrımcılık, adam kayırma, müşteri önünde azarlama vb.) gibi etkenler iş tatmini üzerinde oldukça etkilidir. Daha önce yapılan araştırmaların sonuçlarına bakıldığında da benzer sonuçlar elde edildiği görülmektedir (Akburak, 2019; Çalkın, 2014; Çatır, 2019; Karadut, 2014; Şahin ve ark., 2016;). Otel işletmelerinde yaşanan etik dışı davranışlar neticesinde çalışanların iş tatminin azalması personel veriminin ve verilen hizmet kalitesinin düşmesine neden olacaktır. Bu durum, otel işletmelerinin rezervasyon aşamasında müşterilerine vermeyi taahhüt ettikleri hizmeti verememelerine, işletmeye ve ülkeye karşı olan bakış açısının olumsuz yönde etkilenmesine sebep olabilir. Bu nedenle otel işletmelerinde etik kuralların yerine getirilmesi çok önemlidir.

Bu çalışma, derleme niteliğinde hazırlanmış olup otel işletmelerinde etik konulu yapılan çalışmalara ve seçilen konulara ilişkin bilgi sağlamak amaçlanmıştır. Daha önce yapılan bibliyometrik araştırmalar incelendiğinde araştırmaya konu olan çalışmaların farklı parametreler açısından ele alındığı gözlemlenmiştir. Bu parametrelerden bazıları; atıf sayısı, örneklem türü, örneklem sayısı, sayfa sayısı, yayınlandığı dergi, araştırma metodu, çalışmaların sayfa ve anahtar kelime sayısı, kaynak sayısı şeklindedir. Bu çalışmada, turizm alanında daha önce yapılmış olan bibliyometrik çalışmalarda en sık kullanılan ve gelecekteki araştırmalar için yol gösterici niteliğinin yüksek olduğu düşünülen parametreler baz alınmıştır. Araştırmanın kapsamına yalnızca ulusal alanyazında yayınlanmış makale ve tezler dahil edilmiş olup bu durum araştırmanın sınırlıklarını oluşturmaktadır. Bu nedenle, bundan sonraki yapılacak çalışmalarda araştırmacılar uluslararası çalışmaları da araştırma kapsamına dahil ederek benzer ya da farklı parametreler doğrultusunda daha derinlemesine inceleme yapabilirler.

Ulaşılan araştırmalarda örneklemin seçildiği işletmelerin ağırlıklı olarak 4 ve 5 yıldızlı oteller olduğu görülmüştür. Küçük ölçekli işletmelerin ise çoğunlukla bölgede 4 ve 5 yıldızlı işletmenin bulunmaması ya da yeterli sayıda olmaması nedeniyle seçildiği görülmektedir. Oysaki kurumsalık anlayışının daha düşük olduğu ve etik dışı davranışların daha sık görülebileceği küçük ölçekli işletmelerde etik ile ilgili daha çok araştırma yapılmalıdır. Bu bağlamda, araştırmacıların geleceğe yönelik yapacakları çalışmalarda, örneklem olarak küçük ölçekli işletme çalışanları ve yöneticileri tercih edilebilir, ayrıca küçük ölçekli işletmeler ile büyük ölçekli işletmelerin iş etiğine yaklaşımları kıyaslanabilir.

Hakem Değerlendirmesi: Dış bağımsız.

Çıkar Çatışması: Yazar çıkar çatışması bildirmemiştir.

Finansal Destek: Yazar bu çalışma için finansal destek almadığını beyan etmiştir

Peer-review: Externally peer-reviewed.

Conflict of Interest: The author have no conflicts of interest to declare.

Financial Disclosure: The author declared that this study has received no financial support.

\section{Kaynaklar}

Akbaba, M. (2017). Etik liderlik algısının psikolojik kontrat ihlali ve örgütsel özdeşleşme üzerine etkisi: Turizm sektöründe bir araştırma [The influence of perception of ethical leadership on psychological contract violation and organizational identification: A research in tourism sector] (Yayınlanmamış Doktora Tezi - Unpublished Phd Thesis), Osmaniye Korkut Ata Üniversitesi Sosyal Bilimler Enstitüsü İşletme Anabilim Dalı, Osmaniye. [Crossref]

Akburak, Ş. (2019). Özel konaklama tesislerinde algılanan etik iklimin is tatmini ve iş performansı üzerindeki etkisi: Nevşehir ilinde bir araştırma [The effect of perceived ethical climate on job satisfaction and job performance in special accomodation facilities: A research in Nevsehir province] (Yüksek Lisans Tezi), Nevşehir Hacıbektaş Veli Üniversitesi Sosyal Bilimler Enstitüsü Turizm İşletmeciliği Anabilim Dalı, Nevşehir.

Akova O., Alrawadieh Z., \& Akın G. (2013). Turizm işletmelerinde sosyal sorumluluk ve etik [Social responsibility and ethics in tourism businesses], Turizm işletmeciliği, 301-332, ed. O. Akova, i. Kızılırmak, H. Tanrıverdi, Detay Yayıncılık.

Akșit Âşık, N. (2009). Konaklama işletmelerinde çalışanların yöneticilerin tutum ve davranışlarını etik açıdan değerlendirmelerine yönelik bir araştırma [A study based on the evaluation of the ethics of the managers' behaviour carried out by the employees' in hospitality managements]. Akademik Fener, 89-117.

Arslan, A., \& Kozak, M. (2006). Turizmde gelişme ve etik sorunları: Üniversite öğrencileri üzerine bir araștırma [Development and ethical problems in tourism: A research on university students] Ege Akademik Bakış Dergisi, 6(1), 49-61.

Arslan, E., \& Emeksiz, M. (2016). Konaklama işletmelerinde çevre yönetimi konusunun bibliyometrik profili ve gelecek çalışmalar için öneriler [Bibliometrics profile of environmental management studies in hospitality business and recommendations for future research]. Journal of Multidisciplinary Academic Tourism, 1(1), 1-12. [Crossref]

Ateş, A. (2008). Otel işletmelerinde yöneticilerin iş etiğine yaklaşımları ve izmir ilinde dört ve beş yıldızlı otel işletmelerinde bir uygulama [Approaching of the hotel managers in the business ethics and a practice at the four and 
five star hotels in İzmir] (Yüksek Lisans Tezi), Dokuz Eylül Üniversitesi Sosyal Bilimler Enstitüsü Turizm İşletmeciliği Anabilim Dalı, İzmir.

Bahadır, i. (2010). Beş yıldızlı otel işletmelerinde etik uygulamaları: istanbul örneği [Ethical behaviours on five star hotels: İstanbul example] (Yüksek Lisans Tezi), Sakarya Üniversitesi Turizm Işletmeciliği Anabilim Dalı, Sakarya.

Ballı, E., \& Koca Ballı, A. i. (2017). Otel çalışanlarının örgütsel etik iklim algılarının incelenmesi [Investigation of the organizational ethical climatic perceptions of hotel employees]. Sosyal ve Beşerî Bilimler Dergisi, 9(2), 49-64.

Bayraktar, S. (2004). Otel işletmelerinde halkla ilişkiler konseptinin etik değerler yönünden incelenmesi [Examining public relation concept in the hotel companies through the eyes of ethical values] (Yüksek Lisans Tezi), Kocaeli Üniversitesi, Kocaeli.

Baytok, A., Boyraz, M., Mutlu, H., \& Katırcığlu, E. (2019). Etik ve sosyal sorumluluk konulu bildirilerin bibliyometrisi: Ulusal Turizm Kongreleri Örneği (20092017)] Bibliometry of ethics and social responsibility proceedings: The case of National Tourism Congress (2009-2017)]. Güncel Turizm Araştırmaları Dergisi, 3(1), 65-81. [Crossref]

Bektaş, C. (2008). Etik kodların otel endüstrisine katkıları ve bir alan araștırması [Contributions of ethic codes to hotel Industry and a field Investigation]. Ticaret ve Turizm Eğitim Fakültesi Dergisi, 1-17.

Boğan, E., Çalışkan, C., \& Dedeoğlu, B. B. (2018). Turizm yazınında kurumsal sosyal sorumluluk: Türkiye'de yapılan çalışmaların bibliyometrik analizi [Corporate social responsibility in tourism literature: A bibliometric analysis of studies in Turkey]. Turizm Akademik Dergisi, 5(2), 47-62.

Ceylanlar, N. A. (2017). Helal konseptli otel işletmelerinde çalışanların etik algıları, biray-örgüt uyumu ve örgütsel bağlılıkları arasındaki ilişkinin incelenmesi [Investigation of the relationship between ethical perceptions, individual-organization harmony and organizational commitment of employees in halal concept hotel businesses]. (Yüksek Lisans Tezi), Osmangazi Üniversitesi Sosyal Bilimler Enstitüsü, Eskişehir.

Çalkın, Ö. (2014). Otel çalışanlarının etik lider algılaması, örgütsel bağlılık, işten ayrılma niyeti ve iş tatminiyle demografik ve istihdam özellikleri arasındaki ilişki [Relationship between demographic and employment characteristics and perception of ethical leadership, organizational commitment, turnover intention and job satisfaction of hotel employees] (Yüksek Lisans Tezi), Mustafa Kemal Üniversitesi Sosyal Bilimler Enstitüsü Turizm Iş̧letmeciliği Anabilim Dalı, Hatay.

Çatır, O. (2019). Örgütsel etik değerler ve etik davranışın, örgütsel bağlılığa ve iş tatminine etkisi: Otel işletmeleri örneği [The effect of organizational ethical values and ethical behavior on organizational commitment and job satisfaction: An example of hotel organizations]. Gümüşhane Üniversitesi Sosyal Bilimler Enstitüsü Elektronik Dergisi, 10(1), 60-72.

Çelik, S., Dedeoğlu, B. B., \& Inanır, A. (2015). Relationship between ethical leadership, organizational commitment and job satisfaction at hotel organizations. Ege Akademik Bakış, 15(1), 53-63. [Crossref]

Çiçek, D., \& Kozak, N. (2012). Anatolia: Turizm Araştırmaları Dergisi'nde yayınlanan hakem denetimli makalelerin bibliyometrik profili [Bibliometric profile of refereed articles published in Anatolia: Journal of Tourism Research]. Türk Kütüphaneciliği, 26(4), 734-756 http://www.tk.org.tr/index.php/TK/ article/download/351/343, Erişim Tarihi: 08.08.2020.

Dedeoğlu, B. B., Çelik, S., İnanır, A., \& Altay, H. (2016). Etik liderlik, örgütsel bağlılık ve iş tatmini arasındaki ilişkide: Cinsiyet ve çalışma süresinin farkılaştırıCı (moderate) rolü [Moderate Role of Gender and Working Duration in Relationship Among Ethical Leadership, Organizational Commitment and Job Satisfaction]. Yönetim ve Ekonomi Araştırmaları Dergisi, 14(4), 45-70. [Crossref]

Demir, M. (2014). Otel işletmelerinde etik iklimi-iş performansı ilişkisi [The relationship between ethical climate and job performance in hotel businesses]. Girişimcilik ve Kalkınma Dergisi, 9(2), 363-378.

Diodato, V. P. (1994). Dictionary of bibliometrics. Amerika Birleşik Devletleri: The Hawthorne Press.

Doğan, Y. (2016). İş görenlerde etik tutum ve davranışların oluşmasında örgütsel vatandaşlığın rolü: konaklama işletmelerinde bir uygulama [The role of organizational citizenship in the formation of ethical attitudes and behaviours on the employees: A case study in accommodation businesses] (Yüksek Lisans Tezi), Nevşehir Hacıbektaş Veli Üniversitesi Sosyal Bilimler Enstitüsü Turizm İşletmeciliği Anabilim Dalı, Nevşehir.

Doğantekin, A. (2016). Örgütsel etik iklim ve örgütsel sinizm ilişkisinin belirlenmesi: Konaklama işletmelerinde bir uygulama [Determining the relationship between organizational ethical climate and organizational cynicism: A case study in accommodation establishments] (Yüksek Lisans Tezi), Eski- şehir Osmangazi Üniversitesi Sosyal Bilimler Enstitüsü Turizm İşletmeciliği Anabilim Dalı, Eskişehir.

Dolmacı, N., \& Bulgan, G. (2013). Turizm etiği kapsamında çevresel duyarlılık [Environmental sensitivity in scope of the tourism ethics]. Journal of Yasar University, 29(9), 4853-4871.

Ekiztepe, B. (2011). Konaklama işletmelerinde etik iklimi, örgütsel adalet ve örgütsel bağlılık ilişkisi [The relationship between ethical climate, organizational justice and organizational commitment in the hospitality business] [Yüksek Lisans Tezi), Muğla Üniversitesi Sosyal Bilimler Enstitüsü Turizm İ̧letmeciliği Anabilim Dalı, Muğla.

Erol, S. (2017). Duygusal zekanın etik liderlik davranışı üzerindeki etkisi: Turizm işletmeleri yöneticileri üzerine bir araștırma [Effects of emotional intelligence on ethical leadership behavior: An application to tourism establishment managers] (Yüksek Lisans Tezi), Karabük Üniversitesi Sosyal Bilimler Enstitüsü Turizm İşletmeciliği Anabilim Dalı, Karabük.

Evren, S., \& Kozak, N. (2012). Türkiye'de 2000-2010 yılları arasında yayınlanan turizm konulu makalelerin bibliyometrik analizi [Bibliometric analysis of articles on tourism published in Turkey between 2000-2010]. VI. Lisansüstü Turizm Öğrencileri Araştırma Kongresi, Antalya: Anatolia: Turizm Araştırmaları Dergisi ve Gazi Üniversitesi, 250-266.

Fennell, D. A., \& Przeclawski, K. (2003). Generating goodwill in tourism through et hical stakeholder interactions. (içinde) D.J. Singh ve R.K.S. Timothy Tourism and Host Communities (Der.), 135-152. Dowling: Cabi Publishing. [Crossref]

Göktaş Kulualp, H., \& Erol, S. (2017). Yöneticilerde duygusal zekânın etik liderlik davranışı üzerindeki etkisi [The influence of emotional intelligence on ethical leadership behavior in managers]. Journal of International Social Research, 10(52), 1045-1057. [Crossref]

Güven, E. Ö., \& Çay, A. (2020). Turizm işletmelerinde etik dışı-gayri ahlaki tüketici davranışları [A compilation of the unethical behavior of customers in tourism businesses]. Sosyal Çalışmalar Üzerine Akademik Perspektif Dergisi, 1, 46-66. [Crossref]

Inak, A. (2016). Etik liderlik davranışının örgütsel adalet üzerine etkisi [The impact on organizational justice of ethical leadership behaviour] [Yüksek Lisans Tezi), Nevşehir Hacı Bektaş Veli Üniversitesi Sosyal Bilimler Enstitüsü İşletme Anabilim Dalı, Nevşehir.

Inak, A., Özkoç, A. G., \& Kırıcı, E. (2018). Otel işletmelerinde etik liderlik davranışının örgütsel adalet üzerine etkisi [The effect of ethical leadership behavior on organizational justice in hotel business]. Iğdır Üniversitesi Sosyal Bilimler Dergisi, 14, 286-309.

Ipar, M., \& Esmer, Y. (2015). Turizm ișletmelerinde etik uygulamaların önemi: Kavramsal bir araştırma [Importance of ethical practices in the tourism business: A conceptual Research]. 14. Ulusal İşletmecilik Kongresi, Aksaray.

Kaplan, M. (2010). Otel işletmelerinde etiksel iklim ve örgütsel destek algılamalarının örgütsel bağlılık üzerindeki etkisi: Kapadokya örneği [The effect of ethical climate and organizational support perceptions on organizational commitment in hotel businesses: The case of Cappadocia] (Doktora Tezi), Selçuk Üniversitesi Sosyal Bilimler Enstitüsü Işletme Anabilim dalı Yönetim ve Organizasyon Bilim Dalı, Konya.

Karadut, G. (2014). Etik iklimin ve örgütsel adalet algılarının çalışanların iş tatminine etkisi: Konaklama işletmelerinde amprik bir uygulama [The effect of ethical climate and organizational justice on employees' job satisfaction: An empirical study in hospitality sector] (Yüksek Lisans Tezi), Bahçeşehir Üniversitesi, İstanbul.

Karakaş, G. (2002). Otel işletmelerinde çalışan servis personelinin etik davranışIarı üzerine bir araștırma [A research about the ethical behaviours of service employees in hotel industry] (Yüksek Lisans Tezi), Anadolu Üniversitesi Sosyal Bilimler Enstitüsü, Eskişehir.

Karayiğit, Ç. (2004). Beş yıldızı otel işletmelerinde çalışanların etik davranışları üzerine bir araştırma [Ethical behaviors of five stars hotel's staff (A case of Ankara, İzmir, İstanbul)] (Yüksek Lisans Tezi), Dokuz Eylül Üniversitesi Sosyal Bilimler Enstitüsü Turizm İşletmeciliği Anabilim Dalı, İzmir.

Kavkalı, Z. (2018). Etik örgüt kültürünün sorun bildirme davranışına etkisi: Ankara ilinde faaliyet gösteren dört ve beş yıldızlı otellerde uygulama [Effect of ethical organization culture on whistleblowing implementation in four and five star hotels operating in Ankara province] (Yüksek Lisans Tezi), Mehmet Akif Erson Üniversitesi Sosyal Bilimler Enstitüsü İşletme Anabilim Dalı, Burdur.

Kavkalı, Z., \& Yeşiltaş, M. (2018). Etik örgüt kültürünün sorun bildirme davranışına etkisi: Ankara ilinde faaliyet gösteren dört ve beş yıldızlı otellerde uygulama [The effect of ethical organizational culture on problem reporting behavior: Application in four and five star hotels in Ankara]. Turizm Akademik Dergisi, 5(2), 85-96. 
Kaya, M., \& Maksudunov, A. (2017). Öğrencilerin otel işletmelerindeki iș etiğine yönelik algıları [Students' perception toward business ethics in hotel businesses]. International Conference on Eurasian Economies, 192- 198. [Crossref]

Kozak, N. (1994). Anatolia Dergisi'nde yayımlanan yazılar üzerine bir inceleme [Analysis of the articles pubushed by Anatolia]. Anatolia: Turizm Araștırmaları Dergisi, 5, 22-33.

Kozak, N. (1999). Dünya genelinde "turizm", "rekreasyon" ve "boş zamanlar ve değerlendirilmesi" alanlarında yayınlanmakta olan akademik dergiler üzerinde bir araştırma [An empirical investigation on international journals of tourism, travel, recreaiton and leisure]. Türk Kütüphaneciliği, 13(1), 5-27.

Mirze, S. K. (2010). İşletme [Business]. Literatür Yayıncılık. 394.

Olcay, A., \& Sürme, M. (2015). Turizm işletmelerinde yönetici ve işgören etik davranışlarının karşılaştırılması üzerine bir araştırma [A study on comparison of ethical conducts between executives and employees in tourism businesses]. Uluslararası Sosyal Araştırmalar Dergisi, 8(37), 1114-1131. [Crossref]

Olcay, A., Esen, M., \& Sürme, M. (2018). Turizm işletmelerinde etik ve sinizm kavramlarına genel bir bakıs [A general overview of the concept of ethical and cinism in tourism businesses]. Etik Araştırmaları Sempozyumu, Gaziantep.

Olcay, A., Özkan, B., \& Göçebeler, M. F. (2018). Konaklama ve seyahat işletmelerinde yaşanan etik sorunlar üzerine kavramsal bir değerlendirme [A conceptual assessment of ethical problems in accommodation and travel operations]. Gaziantep University Journal of Social Sciences, 17 Etik Özel Sayı, 1-11. [Crossref]

Oruç, M., \& Türkay, O. (2017). Turizmi konu alan lisansüstü çalışmaların bibliyometrik analizi [Bibliometric analysis of the graduate studies in tourism] Uluslararası Batı Asya Turizm Araştırmaları Kongresi, 252- 258.

Öğüt, A., \& Kaplan, M. (2011). Otel işletmelerinde etiksel iklim algılamaları ile örgütsel bağlılık arasındaki ilişkinin analizi: Kapadokya örneği [The relationship between perceptions of ethical climate types and organizational commitment in hotel businesses: The case of Cappadocia]. Dumlupınar Üniversitesi Sosyal Bilimler Dergisi, 30, 191-206.

Özer, G. (2020). Algılanan nepotizmin etik liderlik aracılığında örgütsel bağlılığa etkisi: Otel işletmelerinde araștırma [The effect of perceptioned nepotism on organizational commitment in ethical leadership: Research in hotel businesses] (Yüksek Lisans Tezi), İskenderun Teknik Üniversitesi Sosyal Bilimler Enstitüsü Turizm ve Otel işletmeciliği Anabilim Dalı, Hatay.

Pelit, E., \& Arslantürk, Y. (2011). Turizm işletmelerinin iş etiğine yönelik uygulamaIarının çalışma yeri tercihindeki önemi: Turizm öğrencileri üzerinde bir araştırma [The importance of practices regarding business ethics of tourism enterprises on workplace choice: A study on tourism student]. Süleyman Demirel Üniversitesi Iktisadi ve Idari Bilimler Fakültesi Dergisi, 16(1), 163-184

Pelit, E., \& Bozdoğan, İ. (2014). Çalışanların örgütsel adalet algılamalarının tükenmişlik düzeyleri üzerindeki etkisi: Kemer'deki beş yıldızlı otel işletmelerinde bir uygulama [Employees' organizational justice perceptions impact on burnout levels: A study on five star hotels in Kemer]. İ̧̧letme Araştırmaları Dergisi, 6(2), 37-66.

Sarı, Ö. (2019). Konaklama sektöründe mesleki etik algısının kurumsal itibara etkisi [Impact of professional ethics perception on corporate reputation in hospitality sector] (Yüksek Lisans Tezi). Karabük Üniversitesi Lisansüstü Eğitim Enstitüsü Turizm İşletmeciliği Anabilim Dalı, Karabük. [Crossref]

Sarı, Y., \& Doğantekin, A. (2016). Konaklama işletmelerinde örgütsel etik iklim ve örgütsel sinizm ilişkisi üzerine bir araştırma [A research on relationship between organizational ethical climate and organizational cynicism in accommodation establishments]. İşletme Araştırmaları Dergisi, 8(3), 222-250. [Crossref]

Sarışık, M., Akova, O., \& Çontu, M. (2006). Otel yöneticilerinin etik politika ve yöntemlere yaklaşımları üzerine amprik bir araştırma [An emprical investigation about ethics policies and procedures of the hotels managers]. Anatolia: Turizm Araştırmaları Dergisi, 7(1), 22-34.

Seçilmiş, C., \& Ceylanlar, N. A. (2019). Birey-örgüt uyumunun etik algı ve örgütsel bağlılık arasındaki aracılık etkisi: Helal konseptli otel işletmelerinde bir araștırma [Mediating effect of individual-organization harmony between ethical perception and organizational commitment: A study in halal concept hotel businesses]. İş Ahlakı Dergisi, 39-73. [Crossref]

Sökmen, A., \& Ekmekçioğlu, E. B. (2013). Yönetici etik davranışlarının sınır birim çalışanlarının motivasyon ve iş tatmini üzerindeki etkisi: Adana'da bir araştırma [The effect of managers' ethical behavior on boundary spanning role employees' motivation and job satisfaction: A research in Adana]. Issletme Araştırmaları Dergisi, 5(4), 87-104.

Şahin, B., Sönmez, B., \& Eraslan, H. (2016). Otel işletmelerinde yöneticilerin çalışanlara karşı etik tutumları [The ethical attitudes of the managers at hotel business towards the employees]. Balıkesir Üniversitesi Sosyal Bilimler Enstitüsü Dergisi, 19(36), 583-603. [Crossref]

Şentürk, F. K. (2014). Etik liderliğin belirleyicileri olarak kişilik, örgüt kültürü, dini yönelim ve çevresel faktörler: Antalya'daki dört ve beş yıldızlı otellerde bir uygulama [Determinants of ethical leadership as personality, culture of organization, religion orientation and environmental factors: Sample of four and five stars hotels in Antalya] (Doktora Tezi), Akdeniz Üniversitesi Sosyal Bilimler Enstitüsü Turizm Iş̧letmeciliği ve Otelcilik Anabilim Dalı, Antalya.

Tayfun, A., Ülker, M., Gökçe, Y., Tengilimoğlu, E., Sürücü Ç., \& Durmaz, M. (2018). Turizm alanında yiyecek ve içecek ile ilgili lisanüstü tezlerin bibliyometrik analizi [Bibliometric analysis of postgraduate theses about food and beverage in the field of tourism]. Journal of Tourism and Gastronomy Studies, 6(2), 523-547. [Crossref]

Temizkan, P., Çiçek, D., \& Özdemir, C. (2015). Sağlık turizmi konusunda yayınlanan makalelerin bibliyometrik profili [Bibliometric profile of articles published on health tourism]. Journal of Human Sciences, 12(2), 394-415. [Crossref]

Tuna, M., \& Yeşiltaş, M. (2013). Liderliğin etik boyutu: Etik liderliğin otel işletmelerindeki işgörenler tarafından algılanması [The ethical dimension of leadership: The perception of ethical leadership by employees in hotel business]. İşletme Araştırmaları Dergisi, 5(3), 184-209.

Tuna, M., \& Yeşiltaş, M. (2014). Etik iklim, işe yabancılaşma ve örgütsel özdeşleşmenin işten ayrılma niyeti üzerindeki etkisi: Otel işletmelerinde bir araştırma [The effect of ethical climate, work alienation and organizational identification on turnover intention: A research on hotel establishments]. Anatolia: Turizm Araştırmaları Dergisi, 25(1), 105-117. [Crossref]

Tuna, M., Bircan, H., \& Yeşiltaş, M. (2012). Etik liderlik ölçeğinin geçerlilik ve güvenilirlik çalışması: Antalya örneği [Reliability and validity of ethical leadership scale: Case of Antalya]. Atatürk Üniversitesi Iktisadi ve Idari Bilimler Dergisi, 26(2), 143-155.

Türk Dil Kurumu (2020) https://sozluk.gov.tr/

Türsab, (2020) https://www.tursab.org.tr/apps/OldFiles//dosya/14733/ bmdto-turizm-icin-kuresel-etik-kurallari-unwto-global-code-of-ethicS-f_14733_4881829.pdf

Tütüncü, Ö., \& Savran, G. (2007). Etik iklim ve tükenmişlik sendromunun kalite yönetim sistemi üzerine etkileri: Bir laboratuvar uygulaması [Effects of ethical climate and burnout syndrome on quality management system: A laboratory practice]. Dokuz Eylül Üniversitesi Sosyal Bilimler Enstitüsü Dergisi, 9(4), 177-218.

Ulutaş, Ö. (2015). Otel işletmelerinde etik iklim algılamalarının ve duygusal emeğin tükenmişlik üzerine etkileri [The effects of ethical climate perceptions and emotional labour on burnout in hotel managements: The case of Nevşehir] (Yüksek Lisans Tezi), Nevşehir Hacı Bektaş Veli Üniversitesi Sosyal Bilimler Enstitüsü İşletme Anabilim Dalı, Nevşehir

Ünlüönen, K., \& Arslan, E. (2012). Otel işletmelerinde çalışanların paraya olan tutumunun mesleki etik değerler açısından incelenmesi [The examination that attitude to money of employees in hotel businesses in terms of professional ethics value]. Elektronik Sosyal Bilimler Dergisi, 11(40), 173-187.

Varinli, I. (2004). Hizmet işletmelerinde çalışanların etik olmayan davranışlarına ilişkin değerlendirmeleri otel işletmelerinde bir uygulama [Evaluations of employees' unethical behaviors in service businesses an application in hotel businesses]. Ege Akademik Bakış Dergisi, 4(2), 44-53.

Yeşiltaş, M. (2012). Örgütsel özdeşleşmenin oluşmasında belirleyiciler olarak etik liderlik ve etik iklim: Otel işletmelerine yönelik bir uygulama [The ethical leadership and climate as the determiners of the organizational identification: A field study on hotel establishments] (Doktora Tezi), Gazi Üniversitesi Eğitim Bilimleri Enstitüsü Turizm İşletmeciliği Ana Bilim Dalı, Ankara.

Yeşiltaş, M., Çeken, H., \& Sormaz, Ü. (2012). Etik liderlik ve örgütsel adaletin örgütsel sapma davranışları üzerindeki etkisi [Ethical leadership and organizational justice on the effect of organizational workplace deviation]. Muğla Üniversitesi Sosyal Bilimler Enstitüsü Dergisi, 28, 18-39.

Yılmazer, A., \& Bahadır, i. (2011). Otel işletmelerinde önbüro çalışanlarının etik algılamalarına yönelik bir araştırma [A study on front office employees' perceptions of ethics in hotel establishments]. Ç.Ü. Sosyal Bilimler Enstitüsü Dergisi, 20(3), 21-40. 